\title{
microRNA Regulation in Estrogen Receptor- Positive Breast Cancer and Endocrine Therapy
}

\author{
Erin W. Howard and Xiaohe Yang ${ }^{*}$
}

\begin{abstract}
As de novo and acquired resistance to standard first line endocrine therapies is a growing clinical challenge for estrogen receptor-positive $\left(E R^{+}\right)$breast cancer patients, understanding the mechanisms of resistance is critical to develop novel therapeutic strategies to prevent therapeutic resistance and improve patient outcomes. The widespread post-transcriptional regulatory role that microRNAs (miRNAs) can have on various oncogenic pathways has been well-documented. In particular, several miRNAs are reported to suppress ERa expression via direct binding with the 3' UTR of ESR1 mRNA, which can confer resistance to estrogen/ERa-targeted therapies. In turn, estrogen/ ERa activation can modulate miRNA expression, which may contribute to $\mathrm{ER}^{+}$breast carcinogenesis. Given the reported oncogenic and tumor suppressor functions of miRNAs in $\mathrm{ER}^{+}$breast cancer, the targeted regulation of specific miRNAs is emerging as a promising strategy to treat $\mathrm{ER}^{+}$breast cancer and significantly improve patient responsiveness to endocrine therapies. In this review, we highlight the major miRNA-ER regulatory mechanisms in context with $\mathrm{ER}^{+}$breast carcinogenesis, as well as the critical miRNAs that contribute to endocrine therapy resistance or sensitivity. Collectively, this comprehensive review of the current literature sheds light on the clinical applications and challenges associated with miRNA regulatory mechanisms and novel miRNA targets that may have translational value as potential therapeutics for the treatment of $\mathrm{ER}^{+}$breast cancer.
\end{abstract}

Keywords: Estrogen receptor alpha (ERa), ER ${ }^{+}$breast cancer, microRNA (miRNA), miRNA biogenesis, Endocrine therapy resistance, ER-receptor tyrosine kinase (RTK) crosstalk

\section{Background}

Estrogen receptor-positive $\left(\mathrm{ER}^{+}\right)$breast cancer accounts for nearly $65 \%$ of breast cancers. In particular, due to the association of hormone levels and ER activation/regulation, the $\mathrm{ER}^{+}$breast cancer subtype is particularly prevalent in postmenopausal women taking hormone replacement therapy. The activation of $E R \alpha$, a major transcription factor, promotes the transcription of a number of target genes that regulate oncogenic processes, including cell cycle progression, cell survival, and epithelial/luminal cell differentiation. Although anti-estrogens, selective ER modulators (SERMs), and selective ER downregulators (SERDs), such as tamoxifen and fulvestrant, are leading treatment strategies that

\footnotetext{
* Correspondence: xyang@nccu.edu

Julius L. Chambers Biomedical/Biotechnology Research Institute, Department of Biological and Biomedical Sciences, North Carolina Central University, North Carolina Research Campus, 500 Laureate Way, NRI 4301, Kannapolis, North Carolina 28081, USA
}

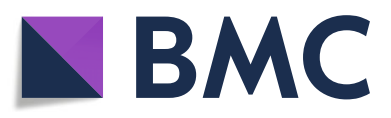

(c) The Author(s). 2018 Open Access This article is distributed under the terms of the Creative Commons Attribution 4.0 International License (http://creativecommons.org/licenses/by/4.0/), which permits unrestricted use, distribution, and reproduction in any medium, provided you give appropriate credit to the original author(s) and the source, provide a link to the Creative Commons license, and indicate if changes were made. The Creative Commons Public Domain Dedication waiver (http://creativecommons.org/publicdomain/zero/1.0/) applies to the data made available in this article, unless otherwise stated. improved $\mathrm{ER}^{+}$breast cancer patient outcomes, therapeutic resistance remains a significant clinical challenge. Therefore, understanding the mechanisms that regulate estrogen/ ER-mediated oncogenic activity will shed light on novel therapeutic targets to more effectively treat $\mathrm{ER}^{+}$breast cancer.

Within the past 15 years, substantial research has highlighted the role of microRNA (miRNA) regulation that can contribute to $\mathrm{ER}^{+}$breast cancer risk or prevention. In particular, studies have not only demonstrated that miRNAs are targets of ER $\alpha$ /hormonal signaling, but have also shown that ER $\alpha$ is a regulatory target of multiple miRNAs. In this review, we highlight miRNA signatures that are associated with $\mathrm{ER}^{+}$and $\mathrm{ER}^{-}$breast cancer subtypes, as well as key tumor suppressor miRNAs and oncomiRs that are deregulated in $\mathrm{ER}^{+}$breast cancer and modulate therapeutic resistance. Importantly, we also 
discuss the potential clinical applications of novel therapeutic strategies targeting miRNAs, and their role in the treatment of therapeutic-resistant $\mathrm{ER}^{+}$breast cancers.

\section{miRNAs Associated with $\mathrm{ER}^{+}$Versus $\mathrm{ER}^{-}$Breast Cancer Subtypes}

The identification miRNA profiles that are associated with specific cancers or predict clinical outcomes has been a major research focus in the past decade or more. In particular, miRNA expression profiling of human breast cancer subtypes, as classified by ER, progesterone receptor, and ErbB2/Her2 receptor statuses, has revealed miRNA signatures that not only correlate with the molecular subtype, but can also serve as potential prognostic markers and indicators of patient responses to facilitate personalized treatment approaches. As summarized in Table 1, numerous reports have identified miRNAs that are differentially expressed in $\mathrm{ER}^{+}$versus $\mathrm{ER}^{-}$ breast cancer samples. Many of the miRNAs that are downregulated in $\mathrm{ER}^{+}$breast cancer are tumor suppressor miRNAs, such as miR-206 $[1,2]$, that function to suppress cell proliferation and survival. The inhibition of tumor suppressor miRNAs consequently contributes to the oncogenic phenotypes associated with $\mathrm{ER}^{+}$breast cancer, such as a high proliferative index in the intrinsic Luminal B subtype of $\mathrm{ER}^{+}$breast cancers [3]. Indeed, the development of targeted therapeutics to upregulate these particular tumor suppressor miRNAs may serve as a promising strategy to treat $\mathrm{ER}^{+}$breast cancer. In contrast, several oncomiRs have consistently been reported to be upregulated in $\mathrm{ER}^{+}$breast cancer, such as miR-10b and miR-21 [4-6]. In particular, the tumor suppressor PTEN, which dephosphorylates PIP $_{3}$ and in turn blocks PI3K/Akt signaling, is a direct target of many oncomiRs that are overexpressed in $\mathrm{ER}^{+}$breast cancer (Table 1). Thus, the attenuation of PTEN-mediated blockage of the PI3K/Akt signaling by the aberrant overexpression of oncomiRs in $\mathrm{ER}^{+}$breast cancer contributes to downstream Akt signaling, which promotes oncogenic cell growth, survival, and migration. The targeted inhibition of these oncomiRs could also provide alternative treatment options for $\mathrm{ER}^{+}$breast cancer patients. As discussed in the following sections, miRNAs play an integral role in the regulation of estrogen/ER $\alpha$ signaling and many miRNAs can also be modulated by ER $\alpha$ activation. Yet, miRNA-mediated regulation of ER $\alpha$ expression/activity and other oncogenic signaling pathways are linked to resistance to standard first-line endocrine therapies.

\section{miRNAs and Estrogen/ERa Regulation miRNAs that Regulate ERa}

Many miRNAs that are associated with $\mathrm{ER}^{+} / \mathrm{ER}^{-}$breast cancer subtypes also directly target or indirectly regulate
ESR1/ER $\alpha$. To this end, many ESR1-targeting miRNAs are downregulated in $\mathrm{ER}^{+}$breast cancer or are upregulated in endocrine therapy-resistant breast cancers (Table 2). In this section, the role of these ESR1-targeting miRNAs in ER signaling regulation will be discussed in context with $\mathrm{ER}^{+}$breast carcinogenesis and prevention.

\section{miR-22}

miR-22 is a classical example of the negative correlation between ESR1-targeting miRNA expression and ER status in breast cancer. As such, miR-22 is downregulated in $\mathrm{ER}^{+}$ breast cancer cell lines, as well as clinical samples [7]. Studies have also consistently reported that miR-22 can post-transcriptionally inhibit ER $\alpha$ expression/function by directly binding to the 3' UTR of ESR1 [7-9]. Indeed, the overexpression of miR-22 blocks ER $\alpha$-dependent cell proliferation and ER-mediated transcriptional activity in vitro [9]. miR-22 was additionally found to indirectly inhibit $E R \alpha$ activity through the direct suppression of the ER $\alpha$ transcriptional coactivator, Sp1 [10]. The induction of cellular senescence by miR-22 overexpression also appeared to correlate with a less invasive cellular phenotype in human breast and cervical cancer cell lines [10]. These in vitro data were consistent with results demonstrating that miR-22 overexpression also promotes senescence and reduces the proliferative index of mammary tumor cells in a murine fat pad orthotopic mammary tumor model. In turn, these miR-22-induced cellular responses suppressed overall mammary tumor growth and reduced the appearance of metastatic tumors in vivo [10]. Together, the direct and indirect mechanisms of ESR1/ER $\alpha$ inhibition utilized by miR-22 suppress the oncogenic phenotypes associated with downstream ER $\alpha$ signaling activity, which makes miR-22 a promising candidate miRNA for therapeutic strategies to treat $\mathrm{ER}^{+}$breast cancer.

\section{miR-206}

miR-206 expression is observably lower in $\mathrm{ER}^{+}$breast cancer versus $E^{-}$breast cancer [1,2]. Likewise, miR-206 is reported to directly target two binding sites in the 3' UTR of ESR1 in vitro [11-14]. ER $\alpha$ coactivators, NCOA1/SRC1 and $N C O A 3 / \mathrm{SRC} 3$, are also putative targets of miR-206 [14]. As well, miR-206 targets GATA3, a key marker for luminal breast cancer that can activate or be activated by $E R \alpha[14,15]$. Indeed, ectopic overexpression of miR-206 significantly represses the oncogenic phenotype associated with ER-mediated cell proliferation and survival, and induces G0/G1 cell cycle arrest in vitro $[1,11,12,14]$. As a potential mechanism of miR-206-induced G0/G1 cell cycle arrest, it has been recently reported that miR-206 directly targets WBP2, which regulates multiple cell cycle proteins involved in G1 to $S$ phase transition, such as $\mathrm{p} 21$, CDK4, and Cyclin D1 [16]. In addition to the suppression of ER $\alpha$-mediated responses and cell cycle regulation, 
Table 1 Differentially expressed miRNAs in $\mathrm{ER}^{+} \mathrm{vs}$. ER ${ }^{-}$breast cancers and their major direct mRNA targets

\begin{tabular}{|c|c|}
\hline miRNAs & $\begin{array}{l}\text { Expression leve } \\
E R^{+}(\text {vs. ER }) \\
\text { breast cancer }\end{array}$ \\
\hline let-7a-c/f & High [4] \\
\hline miR-9 & Low [118] \\
\hline miR-10a/b & High $[4,5]$ \\
\hline miR-18a/b & $\begin{array}{l}\text { High }[57] \\
\operatorname{Low}[2,4,11]\end{array}$ \\
\hline miR-19a/b & Low [83] \\
\hline miR-21 & High [6] \\
\hline miR-22 & Low [7] \\
\hline miR-25 & Low [4] \\
\hline $\mathrm{miR}-26 \mathrm{a} / \mathrm{b}$ & High [36] \\
\hline miR-29b & High [36] \\
\hline miR-30a-d & High $[4,36]$ \\
\hline miR-93 & $\operatorname{Low}[4,119]$ \\
\hline miR-106b & Low [4] \\
\hline miR-130a & High [4] \\
\hline miR-135b & Low [120] \\
\hline miR-142 & Low [4] \\
\hline miR-145 & High [121] \\
\hline
\end{tabular}

Direct miRNA targets [117]

$\mathrm{ER}^{+}$(vs. ER ${ }^{-}$)

breast cancer

CDK6, KRAS, NRAS, HRAS, ITGB3, NF2, HMGA1/2, EWSR1, DICER, AGO1, LIN28A/B, CASP3/8/9, PARP1, IL6/10, E2F2, CCND1/2, CDC34, CDC25A, EZH2, WNT1, MAPK4K4, IRS2, IGF1R, TGFBR1, AKT2, MYC, NUMB

ITGB1, RCOR1, FOXO1/3, CDH1, MAPK1/3, MMP9, TAZ, NOTCH2, HES1, CBX7, E2F1, RAB34, NFKB1, SIRT1, CCNG1, SOCS5, CREB1, DICER1, NF1, CXCR4, TGFBR2, BECN1

MAP3K7, EPHA4, HOXA1, HOXB3, ACTG1, PTEN, USF2, PIK3CAVG, SERPINE1, MMP14, NCOR2, CKDN1A/2A, KLF4, PPARA, NF1, PLK1, CCNA2, ZEB1

ESR1, KRAS, PTEN, CTGF, NR3C1, HIF1A, TGFBR2, SMAD2/4, HSF2, ATM, DICER, BCL2, IRF2, RUNX1, MEF2D, CBX7, TNFAIP3, FOXN1

ESR1, HOXA5, PTEN, CCND1, ERBB4, ATXN1, KAT2B, SOCS1, TGFBR2, BMPR2, KIT, TLR2, TNF, TNFAIP3, FOXP1, BTG1, PIK3CA, MAP3K5, CUL5, AKT1, FGFR2, HIPK1

RASGRP1, CDC25A, BCL2, JAF1, SMARCA4, SPRY2, DUSP10, TIMP3, SOX2/5, MTAP, DOCK5/7, RECK, TGFBR2/3, PTEN, E2F1, TGFBI, SP1, APAF1, BTG2, PDCD4, RHOB, BMPR2, NCOA3, TP63, MSH2/6, TIAM1, EGFR, ERBB2, ICAM1, PPARA, NTF3, COL4A1, SMAD7, MAP2K3, MAT2AV2B, STAT3, LRP6, FZD6, BMI1, SOCS1, FOXO1, CASP8, VEGFA

PTMS, ERBB3, ARPC5, BMP7, PPARA, ESR1, NCOA1, HDAC4/6, HMGB1, SP1, RAB5B, TET2, CDKN1A, WNT1, SIRT1, NET1, TIAM1, MMP14, SNAI1, CXCR2, AKT1, CDK6

BCL2L11, CCL26, KLF4, CDKN1C, KAT2B, TP53, CDH1, MDM2, PTEN, EZH2, SMAD7, ERBB2

HMGA1/2, CCND2, CCNE1/2, ESR1, CDK6, CDC6, PTEN, EZH2, SERBP1, SMAD1/4, REB1, MAP3K2, GSK3B, NOS2, CHD1, FGF9, ATM, HGF, IGF1, LIN28B, DNMT3B, WEE1, ADAM17, CHEK1, ITGA5, DUSP4/5, NRAS, E2F2, PTGS2, JAG1, MYC, GATA4, TAB1, RB1, COX2

TGFB1/3, HDAC4, COL1A1, COL3A1, COL4A1/2, COL5A2, SP1, CDK6, PPP1R13B, PTEN, DNMT1, DNMT3A/B, MCL1, BCL2, VEGFA, TET1/2, CDC42, MMP2/9/15/24, ADAM12, BMP1, HMGA2, GSK3B, INFG, PIK3R1, CCND2, SNAI3, AKT2/3, ITGA6, GATA3, PDGFRA, PDGRA-C, STAT3,

DTL, SMAD1, CDK6, NOTCH1, BECN1, SNAI1, PIK3CD, PRDM1, ABL1, VIM, ESR2, RUNX2, BCL9, SOX4, CBX3, TP53, NCAM1, DNMT1, ITGB3, ATF1, CCND2, CCNE1/2, RPA1, TET1, NOTCH1, KLF9, CAT, ATG12, SERPINE1, DLL4, PDGFRB, BCL2, EIF5A2, ADAM12, HOXA1, SOCS1/3, RUNX2, CASP3, PAK1, MCL1, FOXO3, EZH2

CDKN1A, TP53INP1, E2F1, VEGFA, ITGB8, KAT2B, TUSC2, PTEN, LATS2, TGFBR2, DAB2, SMAD7, ZBTB4, CXCL8, PDCD4, ANG, PTENP1, NEDD4L, MMP3, ZNRF3, FOXA1

ITCH, APP, CDKN1A, E2F1, KAT2B, RB1, PTEN, APC, CASP7, JAK1, SETD2, SMAD7, STAT3, ZBTB4, TWIST1, HIF1A, TRIM8, RUNX3, DAB2, PTENP1, CYBB, TNFSF1OA/11

HOXA5/10, ATXN1, KLF4, PPARG, ESR1, DICER1, RUNX3, RAB5A, SMAD4, TNF, TGFBR2, TGFB1, PPARA, MYC, PTEN, DLL4, MAP3K12, MECP2, MET

APC, KLF4, CASR, PPP2R5C, LATS2, SMAD5, MID1, MTCH2, BMPR2, TGFBR1, FOXO1

RAC1, ARNTL, TGFBR1/2, BOD1, PROM1, ROCK2, CCNT2, TAB2, HMGA1/B1, PTPN23, TP53INP1, IL1A, HSPA1B, SMAD3, ABCG2, LGR5, ZEB1, SIRT1, HIF1A, SOCS1, PTEN, DOCK6

BNIP3, KLF4/5, SOX2/9, MUC1, CDKN1A, ITGB8, STAT1, YES1, CLINT1, IRS1/2, VEGFA, HOXA9, MYC, FLI1, IFNB1, IGF1R, FZD7, CDK4/6, SERPINE1, ESR1, JAG1, NEDD9, PAK4, ERG, NRAS, ADAM17, CDH2, EPAS1, ETS1, CD44, BRAF, SMAD2/3, TGFBR3, CTNND1, SP1/7, TNFSF13, DDX6, ARF6, ADD3, HMGA2, ROCK1, HDAC11, SENP1, NAIP, TUG1, TGFB2, EGFR, ACTB

miR-148 Low [4]

DNMT1/3B, TGIF2, MCL1, IRS1, BCL2, ITGA5/B8, ROCK1, PIK3CA, NRAS, CSF1, CDC25B, MAP3K4/9, MMP7, WNT1/10B, CDKN1B, SERPINE1, SMAD2, MET, USP4, STAT3, ALCAM, TGFB2, AKT2, BAX, $C Y B B, N R P 1$,

miR-150 Low [4]

MYB, MUC4, EGR2, ZEB1, EP300, TP53, CBL, SP1, CREB1, STAT1/5B, CTNNB1, NANOG, MMP14, ZNF350, IGF1R, BIRC5

miR-155 Low [4]

TAB2, SOCS1/6, MSH2/6, MLH1, DET1, SMAD1/2/5, ZNF652, ZIC3, BACH1, APC, TRIM32, RHOA, TP53INP1, SPI1, FOXO3, RUNX2, JUN, ETS1, ICAM1, IRAK3, MYB, SKI, SOX6, FADD, BCL6, NOS3, CCND1, NFKB1, E2F2, MYC, DOCK1, RAD51, PTEN, ERBB2, RPTOR, TFAM, STAT1, SIRT1, TP53

miR-185 Low [36]

RHOA, CDC42, SIX1, DNMT1, EPAS1, ARC, NFATC3, VEGFA, MZB1, HMGA1/2, IGF1R, DUSP4, CASP14, EPHB2, SMADT, TRIM29, TGFB1, AKT1, CCNE1, CDK6, ATR, EZH2

miR-187 Low [4]

miR-190 Low [120]

TNF, BCL6, CRMP1, CYP1B1, FOXA2, ALDH1A3

IGF1, PTEN, BCL2, KCNQ5, MARK2, FOXP2 
Table 1 Differentially expressed miRNAs in $\mathrm{ER}^{+}$vs. ER ${ }^{-}$breast cancers and their major direct mRNA targets (Continued)

\begin{tabular}{|c|c|c|}
\hline miRNAs & $\begin{array}{l}\text { Expression levels in } \\
\mathrm{ER}^{+}\left(\mathrm{vs} \text {. } E R^{-}\right) \\
\text {breast cancer }\end{array}$ & Direct miRNA targets [117] \\
\hline miR-191 & High [36] & MDM4, TMC7, NDST1, SOX4, CDK6/9, SATB1, CEBPB, BASP1, NOTCH2, EGR1, CCND2 \\
\hline miR-193b & High [2] & ESR1, CCND1, PLAU, PRAP1, MCL1, ETS1, MAX, KRAS, RAD51, MYB, NF1, SMAD3, STMN1 \\
\hline miR-199a/b & High [4] & $\begin{array}{l}\text { MET, HIF1A, SMARCA2, CD } 44, \text { EZH2, IKBKB, MAPK1, JUNB, DDR1, MAP3K11, CAV1/2, ERBB2, } \\
\text { ERBB3, MTOR, SIRT1, PTGS2, HSPA5, ATF6, ERN1, CDH1/2, ZHX1, HGF, BECN1, IGF1, NFKB1, } \\
\text { VEGFA, SNAI1, GSK3B, WNT2, FZD4/6, JAG1, HK2, TFAM, CCR7, TGFB2, PIK3CD, PAK4, CDK7, } \\
\text { ITGA3, YAP1, MAP4K3m TGFBR1, FLT1, KDR, FOXA2, SLC27A1, AKT1, MAPK8/9/14, HES1, SET, } \\
\text { DDR1, PAK4, }\end{array}$ \\
\hline miR-206 & Low $[1,2,36]$ & $\begin{array}{l}\text { MET, NOTCH3, ESR1, PAX3, CCND2, CDK4, NR1H3, KRAS, SFRP1, CCND1, ANXA2, NR4A2, SMAD2, } \\
\text { TWF1, CCL2, VEGFA, SOD1, AKT1 }\end{array}$ \\
\hline miR-212 & Low [36] & $\begin{array}{l}\text { RB1, MECP2, TJP1, PEA15, PTCH1, KCNJ2, RBP2, MYC, ACHE, PXN, SOX4, SGK3, SMAD2, MAF, } \\
\text { CCNA2/B1, AGO1 }\end{array}$ \\
\hline $\operatorname{miR}-214$ & High [4] & $\begin{array}{l}\text { EZH2, XBP1, PTEN, MAP2K3, MAPK1/8, ING4, TWIST1, GALNT7, TP53, CTNNB1, JAG1, FGFR1, } \\
\text { NRAS, BIRC5, CDK3/6, RAB15, E2F2, ITCH, SUFU, CPD, PIM1 }\end{array}$ \\
\hline miR-217 & High [120] & SIRT1, ROBO1, PTEN, EZH2, E2F3, DACH1, FOXO3, PTPN14, DMNT1, IGF1R \\
\hline $\operatorname{miR}-218$ & High [120] & $\begin{array}{l}\text { LAMB3, RICTOR, BIRC5/6, LASP1, IKBKB, SP1, VOPP1, ACTN1, ROBO1, SFRP2, HOXB3, DKK2, TOB1, } \\
\text { CDK6, BMI1, HMGB1, LEF1, SLIT3, PDGFRA, GLI2, RUNX2, CDH2, TFF1, EGFR, LGR4, SMO, E2F2, } \\
\text { CDC27, KIT, BCL9 }\end{array}$ \\
\hline miR-221 & High [2] & $\begin{array}{l}\text { CDKN1B/C, BMF, FOXO3, DICER1, KIT, TMED7, ETS1, BBC3, DKK2, DDIT4, TIMP3, ICAM1, FOS, ESR1, } \\
\text { TICAM1, PTEN, TRPS1, WEE1, ZEB2, RB1, APAF1, RECK, SIRT1, MDM2, MGMT, SOCS1/3, ARF4, CXCL12, } \\
\text { IL6R, BECN1, RUNX1/2, DVL2, PIK3R1, MMP2, RAD51 }\end{array}$ \\
\hline $\operatorname{miR}-224$ & High [4] & $\begin{array}{l}\text { KLK10, CXCR4, CDC42, SMAD4, DIO1, NCOA6, FOSB, API5, CDH1, CASP3/7, ATG5, MTOR, FUT4, KRAS, } \\
\text { BCL2, PAK2 }\end{array}$ \\
\hline miR-299 & Low [120] & CDKN1A, SPP1, IGF1 \\
\hline miR-342 & High $[4,120,122,123]$ & GEMIN4, BMP7, DNMT1, ID4, SREBF1/2, CTBP2, BIRC6, E2F1 \\
\hline miR-375 & High [118] & $\begin{array}{l}\text { TIMM8A, PDK1, JAK2, YAP1, MTDH, RASD1, SP1, MAP3K8, LDHB, CIP2A, TP53, ERBB2, IGF1R, PIK3CA, } \\
\text { DEPTOR, RUNX3, MALAT1, MYCN }\end{array}$ \\
\hline miR-519a & Low [124] & CDKN1A, PTEN, YES1, DICER1, TIMP1, RB1, FOXF2, STAT3 \\
\hline miR-520g & Low [122] & VEGFA, SMAD7, MMP2 \\
\hline
\end{tabular}

mRNAs in bold are related to ER regulation and ER target genes. Underlined mRNAs are involved in miRNA biogenesis regulation

miR-206 also directly targets the 3' UTR of MET, which is associated with aggressive breast cancer phenotypes [12, 17]. Together, these reports further validate the miR206-induced effects on ER $\alpha$ expression/activation and ER-mediated breast carcinogenesis [14]. The cell cycle and growth-promoting targets of miR-206 also highlight the potential application of miR-206 expression restoration as a potential therapeutic strategy for $\mathrm{ER}^{+}$breast cancer, particularly the luminal B subtype that is typically characterized by a high proliferative index.

\section{$\operatorname{miR}-221 / 222$}

Various studies have demonstrated that miR-221/222 target oncogenes, as well as tumor suppressor genes. Of particular importance in $\mathrm{ER}^{+}$breast cancer, miR-221/222 targets ESR1 [8, 11]. The negative regulation of ESR1/ $\mathrm{ER} \alpha$ has significant clinical implications related to acquired resistance to endocrine therapies, as discussed later in this review. On the other hand, miR-221/222 can indirectly promote $\mathrm{ER} \alpha /$ estrogen signaling through direct inhibition of $B E C N 1 /$ Beclin1, which is a key regulator of autophagy. Beclin1 can induce autophagy and suppress the tumorigenic properties of MCF-7 breast cancer xenografts in vivo [18]. Although cytokine $m d a-7 / \mathrm{IL}-24$-induced suppression of miR-221 has been found to result in Beclin1-associated autophagic cell death [19], Beclin1 acts as a negative regulator of ER $\alpha$ / estrogen signaling, which may interfere with the efficacy of anti-estrogen therapies [20].

In addition to the regulation of estrogen/ER $\alpha$ signaling, miR-221/222 have a number of tumor suppressor targets, which suggest the oncogenic functional mechanisms of miR-221/222. As a potential mechanism of miR-221/222-associated tumorigenesis, key cell cycle inhibitors have been identified as targets of miR-221/222, which contributes to oncogenic cell cycle progression. In particular, miR-221/222 are negative post-transcriptional regulators of $C D K N 1 B / \mathrm{p} 27^{K i p 1}$, a cell cycle inhibitor [21, 22]. As such, miR-221/222 overexpression suppresses p27 ${ }^{\text {Kip1 }}$ expression and correspondingly promotes $\mathrm{G} 1 / \mathrm{S}$ transition in MCF-7 and MDA-MB-231 breast cancer cell lines $[23,24]$. In vitro studies using breast and other 
Table 2 miRNAs that regulate ESR1/ERa

\begin{tabular}{|c|c|c|}
\hline miRNA & $\begin{array}{l}\text { Effects on ESR1/ERa and known } \\
\text { mechanisms of ER regulation }\end{array}$ & References \\
\hline miR-1 & Suppresses ESR1 expression & [7] \\
\hline miR-9 & $\begin{array}{l}\text { Suppresses ESR1 expression } \\
\triangleright \text { Directly targets ESR1 }\end{array}$ & {$[7,11,125]$} \\
\hline miR-18a/b & $\begin{array}{l}\text { Suppresses ESR1 expression } \\
\triangleright \text { Directly targets ESR1 } \\
\text { Inhibits ERa transcriptional activity }\end{array}$ & {$[7,11,57,82]$} \\
\hline miR-19a/b & $\begin{array}{l}\text { Suppresses ESR1 expression } \\
\triangleright \text { Directly targets ESR1 } \\
\text { Inhibits ERa transcriptional activity }\end{array}$ & {$[57]$} \\
\hline $\mathrm{miR}-20 \mathrm{a} / \mathrm{b}$ & $\begin{array}{l}\text { Suppresses ESR1 expression } \\
\triangleright \text { Directly targets ESR1 } \\
\triangleright \text { Directly targets NCOA3 } \\
\text { Inhibits ERa transcriptional activity }\end{array}$ & [57] \\
\hline miR-22 & $\begin{array}{l}\text { Suppresses ESR1 expression } \\
>\text { Directly targets ESR1 } \\
>\text { Directly targets SP1 }\end{array}$ & {$[7-9,11]$} \\
\hline $\mathrm{miR}-26 \mathrm{a} / \mathrm{b}$ & $\begin{array}{l}\text { Suppresses ESR1 expression } \\
\triangleright \text { Directly targets ESR1 }\end{array}$ & {$[126,127]$} \\
\hline miR-93 & Suppresses ESR1 expression & [11] \\
\hline miR-103 & Suppresses ESR1 expression & [7] \\
\hline miR-107 & Suppresses ESR1 expression & [7] \\
\hline miR-122 & Suppresses ESR1 expression & [7] \\
\hline miR-129 & Suppresses ESR1 expression & [7] \\
\hline $\mathrm{miR}-130 \mathrm{a} / \mathrm{b}$ & Suppresses ESR1 expression & {$[7,11]$} \\
\hline miR-145 & $\begin{array}{l}\text { Suppresses ESR1 expression, but } \\
\text { does not affect ESR1 or ERa } \\
\text { stability } \\
>\text { Directly targets ESR1 }\end{array}$ & [128] \\
\hline miR-146b & Suppresses ESR1 expression & [7] \\
\hline miR-181a-d & Suppresses ESR1 expression & [11] \\
\hline miR-192 & $\begin{array}{l}\text { Suppresses ESR1 expression } \\
>\text { Directly targets ESR1 }\end{array}$ & [129] \\
\hline miR-193b & $\begin{array}{l}\text { Suppresses ESR1 expression } \\
\triangleright \text { Directly targets NCOA3 }\end{array}$ & {$[11,125]$} \\
\hline miR-206 & $\begin{array}{l}\text { Suppresses ESR1 expression } \\
\text { and ER target genes } \\
>\text { Directly targets ESR1 } \\
>\text { Directly targets NCOA1 } \\
\text { and NCOA3 } \\
>\text { Directly targets GATA3 } \\
>\text { Directly targets MET }\end{array}$ & {$[1,7,11-14]$} \\
\hline miR-219 & Suppresses ESR1 expression & [11] \\
\hline miR-221 & $\begin{array}{l}\text { Suppresses ESR1 expression } \\
\triangleright \text { Directly targets ESR1 }\end{array}$ & {$[8,11]$} \\
\hline miR-222 & $\begin{array}{l}\text { Suppresses ESR1 expression } \\
\triangleright \text { Directly targets ESR1 }\end{array}$ & {$[7,8,11]$} \\
\hline $\mathrm{miR}-301 \mathrm{a} / \mathrm{b}$ & Suppresses ESR1 expression & [11] \\
\hline miR-302a-e & Suppresses ESR1 expression & [11] \\
\hline miR-335 & $\begin{array}{l}\text { Suppresses ESR1 expression } \\
\triangleright \text { Directly targets ESR1 }\end{array}$ & [130] \\
\hline miR-372 & Suppresses ESR1 expression & [11] \\
\hline miR-373 & Suppresses ESR1 expression & [11] \\
\hline
\end{tabular}

Table 2 miRNAs that regulate ESR1/ERa (Continued)

\begin{tabular}{lll}
\hline miRNA & $\begin{array}{l}\text { Effects on ESR1/ERa and known } \\
\text { mechanisms of ER regulation }\end{array}$ & References \\
\hline miR-517a/c & Suppresses ESR1 expression & {$[11]$} \\
miR-520a-e & Suppresses ESR1 expression & {$[11]$} \\
miR-548p & Suppresses ESR1 expression & {$[7]$} \\
miR-583 & Suppresses ESR1 expression & {$[7]$} \\
miR-590 & Suppresses ESR1 expression & {$[7]$} \\
miR-643 & Suppresses ESR1 expression & {$[7]$} \\
miR-874 & Suppresses ESR1 expression & {$[7]$} \\
miR-885 & Suppresses ESR1 expression & {$[7]$} \\
miR-934 & Suppresses ESR1 expression & {$[7]$} \\
miR-1231 & Suppresses ESR1 expression & {$[7]$} \\
\hline
\end{tabular}

cancer models have further corroborated the oncogenic role of miR-221/222 by demonstrating TIMP3, PTEN, and PUMA, as putative targets of miR-221/222 [25-29]. The inhibition of miR-221/222 targets induces effects on multiple signaling pathways, which results in a range of cellular responses involved in cell proliferation, apoptosis, and invasion/migration. TIMP3 exhibits anti-cancer actions via the inhibition of metalloproteinases, including several ADAMs, which has been shown to block cell migration and invasion associated with cancer cell metastasis. Moreover, PTEN is an inhibitor of the PI3K/Akt pathway and has been well-established as a tumor suppressor. In MCF-7 ER ${ }^{+}$breast cancer cells, PTEN suppression via miR-221/222 overexpression was associated with PI3K/Akt-mediated promotion of cell proliferation, migration/invasion, and stemness/self-renewal [28]. Furthermore, PUMA is a pro-apoptotic protein that is regulated by p53. Zhang et al. (2010) found that miR-221/222 knockdown induced PUMA-dependent apoptosis in MCF-7 breast cancer and A549 lung cancer cells [29]. The pro-apoptotic function PUMA was further demonstrated by the concurrent induction of Bax and suppression of Bcl2.

In context with miR-221/222 expression and breast cancer in patients, recent reports indicate that miR-221/ 222 expression does not significantly correlate with overall and disease-free survival in breast cancer patients not grouped by subtype [30,31]. However, according to a study by Han et al. (2017), high expression levels of miR-222 in patients with $\mathrm{ER}^{+}$breast cancer were significantly $(P=0.021)$ associated with decreased disease-free survival as compared to $\mathrm{ER}^{+}$breast cancer patients exhibiting low levels of miR-222 [31]. In contrast, the effect of miR-222 expression was not correlated with significant differences in disease-free survival of $\mathrm{ER}^{-}$breast cancer patients. Thus, these reports provide supportive 
evidence that miR-221/222 are key regulators of $\mathrm{ER}^{+}$ breast carcinogenesis.

\section{miRNAs Regulated by Estrogen/ERa}

Estradiol/estrogen signaling has been shown to regulate hundreds of genes through direct ER $\alpha$ binding site interaction, transcription factor activation, and miRNA regulation. miRNA microarray analyses have demonstrated that estradiol can upregulate the expression of numerous individual miRNAs and miRNA families, including the let-7, miR-17-92, and miR-200 family members (Table 3) [32]. In this section, several estradiol-regulated miRNAs will be highlighted and the functional implications of their regulation will be discussed in context with $\mathrm{ER}^{+}$ breast carcinogenesis.

\section{miR-21}

miR-21 is a well-studied oncomiR with anti-cancer targets, like PDCD4 [33], TIMP3 [34], and PTEN [35], and is overexpressed in human breast cancer tissues as compared to healthy breast tissues [34, 36]. Indeed, miR-21 expression levels increase with tumor grade and invasiveness of the cancer [37]. Thus, given the strong association between miR-21 expression and breast cancer, how miR-21 is regulated is an important question. A recent review by Petrović (2016) postulated that the oncogenic role of miR-21 in breast cancer may lie predominately in the regulation of cancer cell growth and invasion rather than the events that contribute to cancer initiation [38]. Moreover, miR-21 expression was reported to exhibit a 2-fold increase in $\mathrm{ER}^{+}$breast cancer cells exposed to estradiol [32, 39]. However, in contrast to reports demonstrating that miR-21 is upregulated in response to estradiol, several studies have reported that estradiol suppresses miR-21 expression in vitro [40-43]. In context with the conflicting effects of estradiol on miR-21 expression, ER $\alpha$ binding sites found in the miR-21 regulatory region are key to determining the upregulation or downregulation of miR-21. In particular, Bhat-Nakshatri et al. (2009) found that unliganded ER $\alpha$ suppresses miR-21 expression, whereas ligand-bound/ estradiol-activated ER $\alpha$ promotes miR-21 upregulation [32]. Additionally, overexpression of a truncated form of $\mathrm{ER} \alpha(\mathrm{ER} \alpha 46)$ may trigger estradiol-induced miR-21 upregulation [44]. ER $\alpha$ activator, AF-1, was also found to be an integral factor in estradiol-induced miR-21 suppression. Although in vivo data are still missing to fully understand and confirm the effects of estradiol on miR-21 expression, these contrasting reports indicate a complex regulatory mechanism between estradiol and miR-21 that may be differentially regulated at different breast cancer stages.

In regards to the potential of miR-21 as a target for breast cancer inhibition, studies using cell models of $\mathrm{ER}^{+}$breast cancer have consistently reported that miR-21 inhibition suppresses $\mathrm{ER}^{+}$breast carcinogenesis $[45,46]$. Interestingly, several reports have indicated that non-pharmaceutical interventions can modulate miR-21 expression. For instance, exercise training can reduce the expression of miR-21, which was postulated to contribute to the decreased mammary tumorigenesis observed in in vivo $\mathrm{ER}^{+}$breast cancer models $[47,48]$. These studies found that exercise downregulated miR-21 and rescued the expression of miR-21 targets, including PDCD4. Moreover, Khori et al. (2015) found that exercise training was equally effective as tamoxifen in reducing estradiol levels and ER $\alpha$ expression, and both tamoxifen and exercise training significantly reduced tumor burden in a BALB/c mouse model of $\mathrm{ER}^{+}$breast cancer [47]. Since PDCD4 downregulation is a major marker of poor prognosis and endocrine therapy resistance in $\mathrm{ER}^{+}$ breast cancer patients [49], the pharmacological, as well as non-pharmacological, suppression of miR-21 represents a promising treatment strategy for $\mathrm{ER}^{+}$breast cancer patients; however, questions remain to be addressed regarding the regulatory mechanisms that control miR-21 expression during breast carcinogenesis, as well as the mechanism by which exercise training alters miR-21 expression. Uncovering these key mechanisms would significantly advance our understanding of how physiological responses can regulate miRNAs that are associated with oncogenic processes.

\section{miR-7}

miR-7 expression is elevated in $\mathrm{ER}^{+}$breast cancer cell lines and is associated with tumor aggressiveness, as indicated by the positive correlation between miR-7 expression and increased tumor size, grade, and metastasis in $\mathrm{ER}^{+}$breast cancer patients $[8,50,51]$. In contrast, miR-7 expression is inversely correlated with the invasiveness of breast cancer cell lines in vitro [52]. Moreover, miR-7 is reported to influence the G2/M cell cycle checkpoint and DNA repair via inhibition of key regulators, such as WEE1, GADD45A, TP53, and ATM [50], which contributes to the reduced proliferative phenotype observed breast cancer cells overexpressing miR-7 [53]. As such, impaired cell cycle and DNA repair associated with miR-7 expression were found to be contributing factors for an accumulation of chromosomal instability. Several groups further explored the mechanisms that regulate miR-7 in $\mathrm{ER}^{+}$versus $\mathrm{ER}^{-}$breast cancer cell lines and determined that miR-7 is upregulated via estrogen-mediated $E R \alpha$ activation in vitro $[8,39]$. As a potential regulatory mechanism that promotes ER dependency for cell proliferation and survival in $\mathrm{ER}^{+}$breast cancer cells, receptor tyrosine kinases (RTKs), such as EGFR and IGF1R, and their associated ligands, including IRS2, are putative targets of miR-7 [8, 54-56]. However, Cui et al. (2017) recently found that miR-7 overexpression downregulated EGFR and IGF1R protein expression 
Table 3 miRNAs regulated by estrogen/ERa activation

\begin{tabular}{|c|c|c|}
\hline miRNA & Known mechanisms of regulation by estrogen/ERa & References \\
\hline \multicolumn{3}{|c|}{ miRNAs upregulated by estrogen/ERa } \\
\hline let-7a-g/i & Located in the intragenic region of an estradiol-regulated gene & {$[32,57]$} \\
\hline miR-7 & & {$[8,39]$} \\
\hline miR-9 & & [131] \\
\hline miR-17 & $\begin{array}{l}\text { ERa-induced MYC/c-MYC upregulation; c-MYC interaction with the } \\
\text { miR-17-92 promoter }\end{array}$ & {$[32,39,57,59]$} \\
\hline miR-18a & & [57] \\
\hline miR-19a/b & & {$[8,57]$} \\
\hline miR-20a & $\begin{array}{l}\text { ERa-induced MYC/c-MYC upregulation; c-MYC interaction with the } \\
\text { miR-17-92 promoter }\end{array}$ & {$[8,39,57,59]$} \\
\hline miR-21 & Contains ERa binding sites in regulatory region & {$[32,39,44,57,59]$} \\
\hline miR-23a & Contains ERa binding sites in regulatory region & [32] \\
\hline miR-24 & & [132] \\
\hline $\operatorname{miR}-25$ & & {$[39,57]$} \\
\hline miR-27b & & {$[39,67]$} \\
\hline miR-29a & & [39] \\
\hline $\mathrm{miR}-30 \mathrm{~b} / \mathrm{c}$ & Located in the intragenic region of an estradiol-regulated gene & [32] \\
\hline miR-32 & & [57] \\
\hline miR-34c & & [39] \\
\hline miR-92a/b & & {$[57,59,132]$} \\
\hline miR-93 & Requires estrogen metabolism-mediated oxidative stress & {$[57,132,133]$} \\
\hline miR-98 & & {$[32,57]$} \\
\hline miR-99b & & [132] \\
\hline miR-101 & & [57] \\
\hline miR-103 & & {$[32,132]$} \\
\hline miR-106a/b & & {$[8,57,59]$} \\
\hline miR-107 & & [32] \\
\hline miR-124 & & [39] \\
\hline miR-127 & & [39] \\
\hline miR-129 & & [59] \\
\hline miR-148a & & [39] \\
\hline miR-149 & & [39] \\
\hline miR-181d & & [39] \\
\hline miR-191 & & {$[39,132]$} \\
\hline miR-196a & Contains ERa binding site in promoter region & [134] \\
\hline miR-200a-c & & {$[32,132]$} \\
\hline miR-203 & & [32] \\
\hline miR-206 & & [39] \\
\hline miR-210 & & [39] \\
\hline miR-301a & & [39] \\
\hline miR-320a/c & & [132] \\
\hline miR-424 & & {$[32,57]$} \\
\hline miR-450 & & [57] \\
\hline miR-489 & & [57] \\
\hline miR-503 & & [135] \\
\hline
\end{tabular}


Table 3 miRNAs regulated by estrogen/ERa activation (Continued)

\begin{tabular}{|c|c|c|}
\hline miRNA & Known mechanisms of regulation by estrogen/ERa & References \\
\hline miR-542 & & [57] \\
\hline $\operatorname{miR}-638$ & & [132] \\
\hline miR-1275 & & [132] \\
\hline miR-1915 & & [132] \\
\hline \multicolumn{3}{|c|}{ miRNAs downregulated by estrogen/ERa } \\
\hline let- $7 \mathrm{a} / \mathrm{c} / \mathrm{f} / \mathrm{g}$ & Transcriptionally repressed by estradiol-induced ER & {$[40,132]$} \\
\hline miR-9 & Located in the intragenic region of an estradiol-regulated gene & [32] \\
\hline miR-15b & & [132] \\
\hline miR-21 & $\begin{array}{l}\text { Mediated by AF-1; Transcriptionally repressed by estradiol-induced ER; } \\
\text { Contains ERa } \\
\text { binding sites in promoter/regulatory region; Mediated by } \\
\text { unliganded ERa }\end{array}$ & {$[40-44,132]$} \\
\hline miR-22 & & {$[57,59]$} \\
\hline miR-23b & Transcriptionally repressed by estradiol-induced ER & [40] \\
\hline $\mathrm{miR}-26 \mathrm{a} / \mathrm{b}$ & & {$[40,132]$} \\
\hline miR-27a/b & $\begin{array}{l}\text { Contains ERa binding sites in regulatory region; Transcriptionally } \\
\text { repressed by } \\
\text { estradiol-induced ER }\end{array}$ & {$[32,40,57]$} \\
\hline miR-127 & & [59] \\
\hline miR-143 & & [32] \\
\hline miR-148a & & [136] \\
\hline miR-181a/b/d & $\begin{array}{l}\text { Contains ERa binding sites in regulatory region; Transcriptionally } \\
\text { repressed by estradiol-induced ER; Mediated by unliganded ERa }\end{array}$ & {$[40,57,137]$} \\
\hline miR-198 & & [57] \\
\hline miR-200c & & [40] \\
\hline miR-206 & & [13] \\
\hline miR-221/222 & Contains ERa binding sites in promoter region & [12] \\
\hline miR-302b & & {$[32]$} \\
\hline miR-487b & & {$[57]$} \\
\hline miR-494 & & {$[57]$} \\
\hline miR-500 & & {$[57]$} \\
\hline miR-506 & & {$[32]$} \\
\hline miR-519e & & [8] \\
\hline miR-524 & & {$[32]$} \\
\hline miR-584 & & [57] \\
\hline miR-663 & & [57] \\
\hline miR-671 & & [57] \\
\hline miR-1228 & & [8] \\
\hline miR-1826 & & [132] \\
\hline
\end{tabular}

in $\mathrm{ER}^{-}$MDA-MB-231 breast cancer cells, but not $\mathrm{ER}^{+}$ MCF-7 breast cancer cells [52]. Although estradiol mediates miR-7 upregulation to confer ER-dependent cell growth, miR-7 downregulation may contribute to endocrine therapy resistance due to the lack of RTK inhibition, which consequently activates compensatory oncogenic signaling pathways. Alternatively, in $\mathrm{ER}^{-}$breast cancers, miR-7 overexpression has been considered as a potential therapeutic strategy to exploit miR-7-mediated suppression of EGFR and IGF1R, which are often overexpressed in triple-negative breast cancer (TNBC). Indeed, miR-7 overexpression can reduce the metastatic potential of TNBC 
cells in vitro [52]. Given the potential breast cancer subtype-specific effects of miR-7 expression, understanding the role of ER-associated regulation of miR-7 and its downstream targets will underscore the clinical applications of targeting miR-7 as novel therapeutic strategies for $\mathrm{ER}^{+}$ breast cancer patients, as well as TNBC patients.

\section{miR-17 and miR-17-92 Cluster}

miR-17 is a member of the miR-17-92 cluster, which includes the miR-17, miR-19, and miR-92 families. The miR-17 family includes miR-17, miR-18a, and miR-20a; the miR-19 family includes miR-19a and miR-19b; and miR-92 belongs to its own family. Based on several studies, estradiol appears to be a major stimulator of many miRNAs in the miR-17-92 cluster. Specifically, miR-17 and miR-20a have been shown to be upregulated by $1.7-$ 3.36 fold in estradiol-treated $\mathrm{ER}^{+}$breast cancer cell lines via $\mathrm{ER} \alpha$-induced $M Y C / \mathrm{c}-\mathrm{MYC}$ upregulation [32, 39, 57, 58]. Consistent with these in vitro microarray data, Kovalchuk et al. (2007) reported that estradiol exposure upregulated miR-17, miR-20a, and miR-92 in a rat model of estradiol-induced breast carcinogenesis, which was accompanied by oncogenic changes in mammary gland morphology, including lobular hyperplasia with increased alveoli and duct numbers [59]. As well, c-MYC was also found to be significantly upregulated in estradiol-exposed rats, further supporting estradiol/ ER $\alpha$-induced c-MYC upregulation as a major regulatory mechanism of the miR-17-92 cluster. Estradiol-induced modulation of gene and histone methylation may also contribute to these associated changes in miRNA expression. Nevertheless, additional studies are necessary as there is a major gap in our understanding of the mechanisms that mediate estradiol/ER $\alpha$-associated regulation of miRNAs.

miR-17 is often characterized as an oncomiR given its inhibition of putative targets involved in tumor suppression, including p21 $[58,60]$. However, several genes that promote cell growth and survival, such as CCND1, STAT3, and E2F1, are also suppressed by miR-17, as well as miR-20a [58, 61-63]. Thus, miR-17 may have oncogenic or tumor suppressor functions that are dependent on specific cellular conditions that determine the need for cell survival. To note, AIB1 (also known as NCOA3 or SRC3) is a putative target of miR-17 that is implicated in breast carcinogenesis and endocrine therapy resistance, indicating that miR-17 may also function as a regulator of ER $\alpha$ signaling [64-66]. As well, it has recently been reported that induced overexpression of miR-17 can sensitize cells to tamoxifen-mediated apoptosis in vitro [63]. Given the evidence that miR-17 can exhibit functions as both an oncomiR and a tumor suppressor, additional studies are warranted to elucidate the microenvironmental/cellular context that may influence the cancer-promoting or anti-cancer properties of miR-17 and its related family of miRNAs.

\section{$\mathrm{miR}-27 \mathrm{a} / \mathrm{b}$}

Reports examining the effects of estradiol on miR-27a/b expression have produced conflicting data. For instance, microarray data have indicated that estradiol can elicit a 0.6 to 2.65 fold change in $\mathrm{miR}-27 \mathrm{a} / \mathrm{b}$ expression in MCF-7 cells [32, 39, 40, 67]. Despite conflicting in vitro reports, Tang et al. (2012) confirmed that high miR-27a expression and low ZBTB10 expression, a putative target of miR-27a, were associated with poor patient survival [68]. In context with the regulatory role of $\mathrm{miR}-27 \mathrm{a} / \mathrm{b}$ in $\mathrm{ER}^{+}$breast cancer, ZBTB10 is a major inhibitor of Sps, including Sp1 [69, 70]. Sp1 interactions with $E R \alpha$ are integral for ER $\alpha$ transcriptional activity; therefore, the indirect regulation of $\mathrm{Sp} 1$ via miR-27a may direct the activation or inhibition of $E R \alpha$ activity. miR-27b is also shown to target $C Y P 1 B 1$, a gene that encodes for an enzyme that is important for the hydroxylation of estradiol, which can produce free radicals and lead to DNA damage [71]. Since miR-27b expression is reported at higher levels in normal breast tissues as compared to breast cancer tissues [71], the suppression of miR-27b by estradiol [32] may be a cancer-promoting mechanism that results in the increased expression of CYP1B1 and subsequent DNA damage. Moreover, miR-27b levels are also reduced in tamoxifen-resistant breast cancer cell lines as well as patient samples, which are associated with the increased expression of miR-27b targets NR5A2/LRH1 and CREB1 [67]. The upregulation of NR5A2 has a particularly important oncogenic function as it directly binds to the ER $\alpha$ promoter to stimulate transcription [72] and promote MYC expression [73], which has previously been reported to upregulate the expression of other oncomiRs (i.e. miR-17 and miR-20a) [58]. Thus, further studies are needed to dissect the factors that regulate the balance between the physiological and oncogenic functions of miR-27a/b.

\section{Feedback Mechanisms that Regulate Estrogen/ER Signaling}

Although it has been well-established that miR-206 directly targets the 3' UTR of ESR1/ER $\alpha$ in $\mathrm{ER}^{+}$breast cancer cells [1, 11, 12], Adams et al. (2007) identified a feedback mechanism where estradiol and other ER $\alpha$ agonists can significantly inhibit miR-206 expression, while ER $\beta$ agonists promoted miR-206 expression (Fig. 1a) [13]. In contrast, microarray data reported by Masuda et al. (2012) found that estradiol markedly upregulated miR-206 by 3.35-fold in MCF-7 cells, which would consequently inhibit ER $\alpha$ expression and activity [39]. Lee et al. (2013) further suggested a functional role of ER $\alpha$-mediated miR-206 regulation during physiological mammary gland development as miR-206 was found to 
be repressed downstream of ER $\alpha$, indicating a potential role in ductal growth regulation [74]. Other estrogen/ ER-associated miRNAs may also participate in regulatory loops to modulate estrogen/ER signaling. miR-221/222, which directly target ESR1, are other key examples as $E R \alpha$ knockdown in MCF-7 cells revealed that miR-221/ 222 can be regulated by ER $\alpha$ activity in vitro (Fig. 1b) [12]. Specifically, estrogen-mediated ER $\alpha$ activation recruited corepressors NCoR and SMRT to the transcription start site of miR-221/222. Garofalo et al. (2009) also proposed a mechanism of miR-221/222 upregulation in non-small cell lung cancer (NSCLC) and hepatocellular carcinoma (HCC) models involving c-MET/MET-mediated upregulation of the transcription factor AP-1 [25]. This mechanism may be potentially translated to miR-221/222 upregulation associated with $\mathrm{ER}^{+}$breast cancer models; however, further in vitro and in vivo evidence is warranted.

As previously discussed, miR-17 and miR-27a/b may also be involved in estrogen/ER $\alpha$ pathway regulation. The expression of these miRNAs has been found to be upregulated by estradiol/ER $\alpha$ in numerous reports [32, $39,58,59]$; however, the attenuation of their putative targets involved in ER $\alpha$ regulation, such as $A I B 1$ by miR-17 and ZBTB10 by miR-27a, results in indirect ER $\alpha$ signaling inhibition and activation, respectively (Fig. 1c) $[64,67,69]$. Additionally, miR-375 is reportedly involved in a feedback mechanism that regulates ER $\alpha$ expression and signaling. Simonini et al. (2010) found that hypomethylation of the miR-375 promoter epigenetically stimulated miR-375 expression, which was positively correlated with ER $\alpha$ expression and activity [75]. The authors further identified $R A S D 1$, a negative regulator of $\mathrm{ER} \alpha$, as a direct target of miR-375 (Fig. 1d). In contrast, others have reported that miR-375 can directly target Sp1, an ER $\alpha$ coactivator, in $\mathrm{HCC}$, colorectal, and cervical cancer models [76-78]. Although miR-375-mediated Sp1 regulation has not been verified in breast cancer models, this potential mechanism highlights a facet of miR-375-associated estrogen/ER $\alpha$ signaling regulation. Collectively, miRNA involvement in positive/negative feedback loops that regulate ER $\alpha$ activity can, at times, produce contradictory cellular responses, which further underscores the complexity of these regulatory networks that need to be unraveled to advance the potential development of miRNAtargeting therapeutics for $\mathrm{ER}^{+}$breast cancer.

\section{miRNAs and Drug Resistance}

In $\mathrm{ER}^{+}$breast cancer, several therapeutic strategies are employed to selectively inhibit estrogen/ER $\alpha$ signaling, including ER antagonists that directly bind to ER $\alpha$ and enzyme inhibitors that block estrogen synthesis. However, de novo and acquired resistance to conventional endocrine therapies can occur in more than $30 \%$ of patients
$[79,80]$. Due to general targeting of estrogen/ER signaling, cross-resistance to multiple endocrine therapies is also a major concern. Therefore, elucidating the mechanisms of therapeutic resistance is integral to preventing and overcoming this significant clinical challenge. Several mechanisms of endocrine therapy resistance have been identified, including decreased ER expression, ER-independent signal transduction, and even miRNA regulation. Notably, miRNAs are promising targets for the novel therapeutic strategies due to the broad range of mRNA targets that ultimately regulate many of the ER-independent mechanisms associated with endocrine therapy resistance. In this section, resistance to tamoxifen, fulvestrant, and aromatase inhibitors will be discussed in context with miRNAs that may confer the resistant phenotype and/or may be promising therapeutic targets to increase patient responsiveness to the first-line endocrine therapies.

\section{Tamoxifen Resistance}

As discussed in the previous section, although miR-221/ 222 are shown to target and inhibit the translation of oncogenic proteins associated with $\mathrm{ER}^{+}$breast cancer, several studies have linked miR-221/222 expression to tamoxifen resistance. Miller et al. (2008) determined that miR-221/222 expression was positively correlated with resistance to tamoxifen-mediated cell growth inhibition, apoptosis, and cell cycle inhibition in MCF-7 breast cancer cells [23]. In context with the 3' UTR of CDKN1B mRNA as a known target of miR-221/222 [21, 22, 24], CDKN1B mRNA/p27 ${ }^{\text {Kip } 1}$ protein regulation appears to be an essential mediator of miR-221/222-induced tamoxifen resistance in MCF-7 cells. Indeed, ectopic overexpression of p27 ${ }^{K i p 1}$ rescues tamoxifen sensitivity in MCF-7 cells [23]. A report by Wei et al. (2014) suggested that exosomal secretion of miR-221/222 may be a mechanism that confers tamoxifen resistance [81]. Interestingly, secreted exosomes from tamoxifen-resistant MCF-7 cells contained miR-221/222 and could be transferred into tamoxifen-sensitive cells, which rendered the cells resistant to tamoxifen-induced cell growth inhibition and apoptosis. Consistent with miR-221/222 upregulation, ER $\alpha$ and $\mathrm{p} 27^{\text {Kip } 1}$ protein levels were also decreased in the MCF-7 cells exposed to exosomes from tamoxifen-resistant cells. As another potential mediator of tamoxifen resistance, miR-21 was found to be activated by 4-hydroxytamoxifen (4-OHT)and fulvestrant-mediated blockage of estrogen/estradiol [41]. This in vitro study presented evidence of miR-21 expression as a resistance factor in $\mathrm{ER}^{+}$breast cancer; nevertheless, additional studies are warranted to fully understand the oncogenic mechanisms of miR-21 and miR-221/222 associated with therapeutic resistance.

$E R \alpha$ expression is a critical factor that mediates tamoxifen resistance. As such, ER $\alpha$ suppression by miRNAs has been shown to block the efficacy of tamoxifen. In this regard, the expression levels of ESR1/ER $\alpha$-targeting 


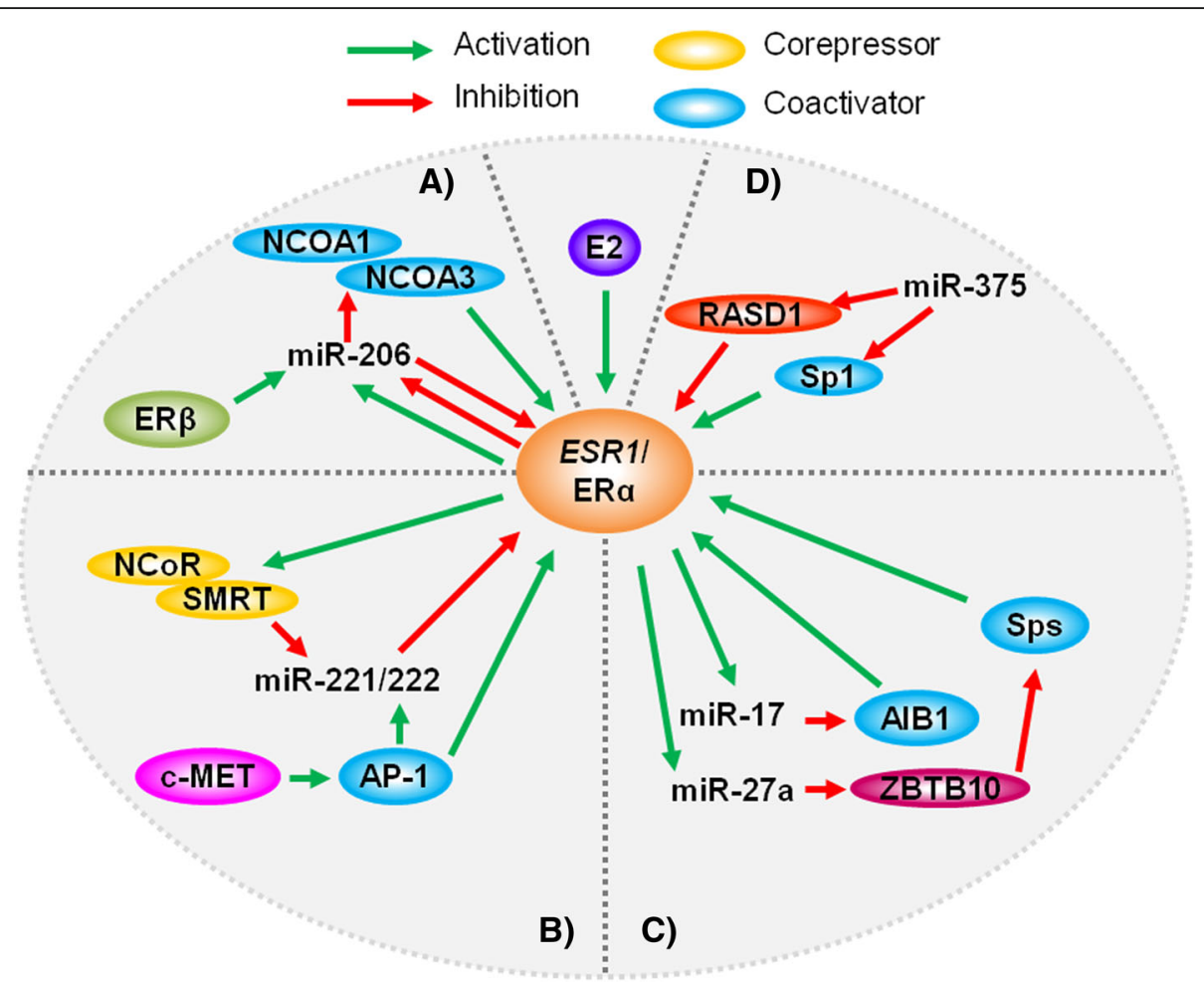

Fig. 1 Feedback mechanisms that regulate estrogen/ERa signaling. miR-206 (a), miR-221/222 (b), miR-17 and miR-27a (c), and miR-375 (d) are involved in regulatory mechanisms that can contribute to the activation or inhibition of estrogen/ERa signaling

miRNAs, such as miR-221/222 [8], miR-18a [82], $\mathrm{miR}-19 \mathrm{a} / \mathrm{b}$ [83], and miR-22 [9], may predict the clinical responsiveness of $\mathrm{ER}^{+}$breast cancer patients to tamoxifen. Moreover, Beclin1-overexpressing MCF-7 cells exhibited estradiol-induced colocalization of Beclin1 and ER $\alpha$, which contributed to decreased sensitivity to tamoxifen derivatives, raloxifene and 4-OHT [20].

\section{Tamoxifen Sensitization}

In recent years, several strategies have been proposed to increase breast cancer cell sensitivity to tamoxifen. First, targeted inhibition of miRNAs associated with tamoxifen resistance has provided in vitro evidence of increased tamoxifen sensitivity in $\mathrm{ER}^{+}$breast cancer cells. As such, miR-221/222 knockdown upregulated TIMP3 mRNA and protein expression, which corresponded with enhanced tamoxifen-induced inhibition of cell viability in MCF-7 ER ${ }^{+}$breast cancer cells [26]. To note, miR-221/ 222 inhibition did not affect the responsiveness of MDA-MB-231 triple-negative breast cancer cells to tamoxifen, which is consistent with the link between miR-221/222 expression, estrogen/ER $\alpha$ signaling, and tamoxifen activity. Furthermore, miR-221/222 silencing in tamoxifen-resistant MCF-7 cells protected wild-type cells from exosomal miR-221/222-induced tamoxifen resistance [81].
The inhibition of known oncomiRs, such as miR-21, has also provided a promising strategy to suppress $\mathrm{ER}^{+}$breast carcinogenesis and enhance the effects of tamoxifen and other anti-estrogen treatments. Recently, Yu et al. (2016) reported that ectopic suppression of miR-21 via transfection with a miR-21 inhibitor results in Beclin1-mediated autophagic cell death, as well as increased sensitivity to both tamoxifen and fulvestrant, as demonstrated by an increased induction of apoptosis in vitro [46]. Moreover, nanoparticles co-loaded with anti-miR-21 and 4-OHT have shown promising anti-proliferative effects on MCF-7 $\mathrm{ER}^{+}$breast cancer cells in vitro [84]. As compared to the 4-OHT treatment alone, the anti-miR-21 + 4-OHT nanoparticles induced a significant decrease in cell proliferation, which was accompanied by cell cycle arrest in G2/M phase. Furthermore, miR-34a expression has been reported to suppress miR-21 via the post-transcriptional inhibition of CD24 and Src, which were found to induce miR-21 expression, in in vitro breast and colon cancer models [85]. Importantly, CD24 expression has been positively correlated with ER $\alpha$ and ErbB2 status in breast cancer [86], and Src is involved in the phosphorylation/ activation and intracellular localization of ER $\alpha$ and subsequent DNA synthesis [87]. Together, these data provide supportive evidence for testing miR-34a mimics and/or miR-21 inhibitors to treat $\mathrm{ER}^{+}$breast cancer and to overcome tamoxifen resistance. 
Alternatively, the induced upregulation of miRNAs that are reportedly downregulated in tamoxifen-resistant cells has been shown to significantly improve $\mathrm{ER}^{+}$breast cancer cell sensitivity to tamoxifen. For instance, miR-378 is downregulated in tamoxifen-resistant MCF-7 cells and is found at lower levels in human breast cancer tissues as compared to normal adjacent tissues [88]. Low miR-378 expression was further associated with decreased recurrence-free survival in $\mathrm{ER}^{+}$breast cancer patients taking tamoxifen as an adjuvant therapy [88]. Importantly, key mechanistic data suggest that miR-378-mediated inhibition of GOLT1A, which is involved in the fusion of transport vesicles with the Golgi membrane, plays a critical role in tamoxifen resensitization in vitro, which is further corroborated by clinical data demonstrating increased relapse-free survival in breast cancer patients with low GOLT1A expression. miR-27b is also reportedly downregulated in tamoxifen-resistant $\mathrm{ER}^{+}$breast cancer cells and patient tumor tissue samples [67, 89]. Zhu et al. (2016) showed that miR-27b-3p is downregulated in tamoxifen-resistant $\mathrm{ER}^{+}$breast cancer cells [67]. Interestingly, studies have reported conflicting miR-27b regulation by estrogen/estradiol. As previously mentioned, miR-27b was identified as a miRNA that is repressed by estradiol by 0.6 fold in MCF-7 cells [32]. In contrast, a recent report found that estradiol upregulated miR-27b-3p expression, and tamoxifen dose- and time-dependently suppressed miR-27b-3p expression in MCF-7 and T47D cells [67]. Moreover, overexpression via miR-27b mimics significantly enhanced $\mathrm{ER}^{+}$breast cancer cell sensitivity to tamoxifen-induced cell growth inhibition and apoptosis. miR-27b overexpression also rendered tamoxifen-resistant breast cancer cells sensitive to tamoxifen in both in vitro cell line and in vivo xenograft tumor models [67]. The upregulation of miR-27b sensitization to tamoxifen in $\mathrm{ER}^{+}$ breast cancer cells was further associated with the suppression of direct targets, NR5A2/LRH1 and CREB1, which are implicated in tamoxifen resistance via the induction of ER $\alpha$ and aromatase, respectively [72, 90]. The negative correlation between miR-27b and NR5A2 and CREB1 expression has further been corroborated in human breast cancer tissues from tamoxifen-untreated and tamoxifen-resistant patients, suggesting that miR-27b may be a predictive marker for tamoxifen responsiveness, as well as a potential therapeutic target to overcome tamoxifen resistance [67].

Modulated miR-342 expression is also correlated with tamoxifen resistance/sensitivity in $\mathrm{ER}^{+}$breast cancer. Numerous studies have consistently reported that miR-342 is downregulated in tamoxifen/4-OHT-resistant breast cancer cell lines and clinical samples [23, 91, 92]. In particular, miR-342 expression was reduced by $55 \%$ in 4-OHT-resistant MCF-7 cells as compared to parental cells [23]. Likewise, miR-342 downregulation is associat ed with tamoxifen treatment failure and decreased overall survival in $\mathrm{ER}^{+}$breast cancer patients [30, 91]. In preclinical models of tamoxifen resistance, restoring the expression of miR-342 markedly sensitized $\mathrm{ER}^{+}$breast cancer cells to tamoxifen-mediated cell growth inhibition and apoptosis [91]. Interestingly, $\mathrm{He}$ et al. (2013) reported that miR-342 expression is positively correlated with ER $\alpha$ expression in clinical breast cancer samples and breast cancer cell lines, which is proposed as a potential mechanism of enhanced tamoxifen sensitivity in breast cancer cell lines with ectopic miR-342 overexpression [92]. Together, these reports indicate that miR-342 is not only a potential biomarker for $\mathrm{ER}^{+}$breast cancer patient survival and tamoxifen efficacy, but also may serve as a therapeutic target to enhance patient responses to tamoxifen.

The overexpression of EGFR, ErbB2, and other RTKs is linked to tamoxifen resistance as compensatory oncogenic signaling pathways $[93,94]$. Therefore, targeted inhibition of these pathways has been presented as a potential strategy to overcome tamoxifen resistance. For example, miR-26a/b are reported to target the 3' UTR of ERBB2 and suppress ErbB2 protein expression in tamoxifen-resistant $\mathrm{ER}^{+}$breast cancer cells. In particular, miR-26 is suggested to be suppressed by estrogen/estradiol [95] and is found to be downregulated in tamoxifen-resistant breast cancer cells. However, high miR-26a expression is associated with decreased expression of known cell cycle regulatory targets, including Cyclin E1, EZH2, and Cdk1, and positive clinical outcomes in patients with metastatic breast cancer taking tamoxifen [96]. Overexpression of the tumor suppressor miR-34a has also been reported to suppress ErbB2 expression and breast cancer cell growth and invasion [97]. Given the oncogenic function of ErbB2 in acquired tamoxifen resistance, miR-34a expression may be a prognostic target to predict tamoxifen responsiveness in $\mathrm{ER}^{+}$breast cancer patients. In addition, the knockdown of Beclin1, a target of miR-221 [19], has been reported to suppress ErbB2 expression and restore tamoxifen sensitivity in resistant MCF-7 cells in vitro [98]. Consistently, clinical data from $\mathrm{ER}^{+}$breast cancer patients taking tamoxifen have demonstrated that high Beclin1 expression is correlated with decreased patient survival [98]. Based on reports highlighting the oncogenic role of Beclin1 in $\mathrm{ER}^{+}$breast cancer, miR-221-induced inhibition of Beclin1 would theoretically inhibit $\mathrm{ER}^{+}$breast carcinogenesis and promote tamoxifen sensitivity in $\mathrm{ER}^{+}$breast cancers. Nevertheless, the anti-cancer mechanism involving Beclin1 knockdown, in context with reports indicating the cancer-promoting activities of miR-221/222, further adds to the complex role of miR-221/222 in $\mathrm{ER}^{+}$breast cancer promotion and inhibition.

\section{Fulvestrant Resistance}

Due to the different anti-cancer mechanisms of tamoxifen and fulvestrant (also known as ICI-182,780 or Faslodex), 
Zhou et al. (2018) recently reported that miRNA profiles generally differ between fulvestrant- and tamoxifen-resistant MCF-7 breast cancer cells [99]. Nevertheless, there are some miRNAs that are associated with resistance to both therapeutic agents because of the broad range of mRNA targets. As such, miR-21 overexpression has also been found to confer tamoxifen and fulvestrant resistance through the inhibition of its direct targets, including PTEN [46]. Interestingly, treatment with fulvestrant can upregulate miR-21 expression [49], which indicates that miR-21 may have a critical role in the development of fulvestrant resistance.

Other examples of miRNAs that are involved in both tamoxifen and fulvestrant resistance are miR-221/222. miR-221/222 are upregulated in both tamoxifen- and fulvestrant-resistant MCF-7 cells, but to a greater extent in the fulvestrant-resistant cell line, and confer the resistant phenotype [100]. Similar to the report indicating that exosomes can transfer miR-221/222 to promote tamoxifen resistance in nearby cells, microvesicles containing miR-221 produced from cancer-associated fibroblasts can transfer fulvestrant resistance to non-tumor cells in an IL6-dependent manner [101]. Fulvestrant, but not tamoxifen, also significantly upregulates miR-221/222 expression in parental MCF-7 cells, which may be an indicator of the development of fulvestrant-resistance. As well, miR-221/ 222 upregulation promotes fulvestrant resistance via multiple pathways, including the targeted inhibition of ER $\alpha$ and $\mathrm{p} 27^{\text {Kip } 1}$. The inhibition of ER $\alpha$ upon miR-221/222 overexpression consequently induces ER $\alpha$-independent cell growth, which is a mechanism that confers fulvestrant resistance. RTK and Wnt/B-catenin pathways have been implicated in ER $\alpha$-independent cell growth in fulvestrantresistant cells $[100,102]$. Particularly, the expression of critical genes involved in the $\mathrm{Wnt} / \beta$-catenin pathway, including CTNNB1, LRP6, and WNT11, was previously found to be upregulated in fulvestrant-resistant MCF-7 cells, which coincided with hypomethylation of their gene promoters [102]. Moreover, $\beta$-catenin overexpression was found to confer fulvestrant resistance, but to a lesser extent than miR-221/222 overexpression, suggesting that $\mathrm{miR}-221 / 222$ regulation of other targets is necessary to induce fulvestrant resistance. Together, these reports indicate that perhaps miR-221/222 may functionally regulate Wnt/ $\beta$-catenin signaling through an epigenetic mechanism that modulates promoter methylation.

More recently, the activation of other oncogenic signaling pathways has been connected to miR-221/222 expression and acquired fulvestrant resistance, including the upregulation of key markers in the TGF $\beta$, Notch, Jak-STAT, MAPK, and p53 signaling pathways [100]. Furthermore, miR-221/ 222 overexpression promoted TGF $\beta$-induced cell survival in parental MCF-7 cells, whereas miR-221/222 knockdown enhanced the tumor suppressor activities of TGF $\beta$ with significantly decreased cell survival in fulvestrant-resistant MCF-7 cells. Thus, Rao et al. (2011) postulated that miR-221/222 may have an additional regulatory role that preferably stimulates the oncogenic function of TGF $\beta$ to promote fulvestrant-resistant breast cancer cell growth [100].

\section{Fulvestrant Sensitization}

Integrative computational analyses of miRNA-gene expression in endocrine therapy-resistant breast cancer cell lines have revealed a miR-222-CDKN1B/p27 ${ }^{\text {Kip } 1}$ expression network that is conserved in both tamoxifen-resistant and fulvestrant-resistant MCF-7 cells [103]. Similar strategies to enhance $\mathrm{ER}^{+}$breast cancer cell sensitivities to tamoxifen and fulvestrant are being tested. The knockdown of oncogenic miR-221/222 in fulvestrant-resistant MCF-7 cells resulted in the concurrent inhibition of cell growth and colony formation, as well as the upregulation of $\mathrm{p} 27^{\text {Kip } 1}$ upon fulvestrant treatment [100]. In addition to the well-studied regulatory function of miR-221/222 on $\mathrm{p} 27^{\text {Kip } 1}$ and ER $\alpha$ expression, mRNA expression profiling revealed that 428 gene probes were upregulated and 224 gene probes were downregulated in response to miR-221/222 knockdown in fulvestrant-resistant MCF-7 cells. These data highlight the widespread and complex functional role of miR-221/222 in fulvestrant resistance, and uncover novel pathways or key mediators, such as Wnt/ $\beta$-catenin, TGF $\beta$, EGFR, and ErbB2, that may be valuable targets for future therapeutic development or combined treatment strategies. Importantly, the targeted inhibition of EGFR, ErbB2, and $\beta$-catenin in tamoxifen-resistant and fulvestrant-resistant cells has demonstrated sensitization to the growth inhibitory effects proportional to the degree of phosphorylation/ activation of these targets in the parental and resistant cells [102]. Given the correlation between these oncogenic compensatory pathways that promote ER $\alpha$-independent cell growth and tamoxifen/fulvestrant resistance, the targeted inhibition of miR-221/222 expression is a promising strategy to prevent the acquisition of fulvestrant resistance and even treat fulvestrant-resistant breast cancer patients.

The regulation of autophagy is emerging as another potential strategy to overcome fulvestrant resistance. It was recently reported that the combined inhibition of EGFR/ErbB2 (via lapatinib) and c-ABL (via imatinib) in fulvestrant-resistant breast cancer cells significantly inhibited cell growth and autophagy [104]. These anti-cancer effects were found to be associated with the upregulation of miR-375, which has previously been linked to PDK1/Akt/ mTOR-independent inhibition of autophagy, as indicated by decreased autophagosome formation, ATG7 gene expression, and LC3-II protein expression, in HCC in vitro and in vivo [76]. In contrast to the anti-cancer effects resulting from miRNA-induced suppression of autophagy in fulvestrant-resistant cells, a report using parental MCF-7 cells found that miR-21 knockdown increased autophagic 
cell death via activation of its direct target PTEN and subsequent inhibition of the PI3K/Akt/mTOR pathway to enhance sensitivity to tamoxifen and fulvestrant [46]. To note, the effects of miR-21 knockdown on autophagy in resistant breast cancer cells has not been investigated. Moreover, increased autophagy has been reported in cells treated with 4-OHT and fulvestrant, which may be a potential mechanism that leads to the acquisition of therapeutic resistance [105]. miR-214 overexpression was shown to suppress 4-OHT- and fulvestrant-induced autophagy in MCF-7 cells through the inhibition of its direct target UCP2. Importantly, miR-214-mediated suppression of UCP2 led to the inhibition of the PI3K/Akt/mTOR pathway [105]. Based on these findings, the regulation of autophagy may have different consequences in context with the therapeutic sensitivity/resistance of the cells, which warrants further investigation. Advancing our understanding of the role of autophagy in fulvestrant/tamoxifen resistance will support the development of novel strategies that modulate autophagy to prevent or overcome endocrine therapy resistance.

\section{miRNA-Regulated Pathways Associated with Aromatase Inhibitor (AI) Resistance}

AIs, such as letrozole and anastrozole, are typically prescribed to postmenopausal $\mathrm{ER}^{+}$breast cancer patients. However, the prolonged estrogen deprivation in these patients can lead to acquired AI resistance, which is a critical clinical challenge. Emerging studies have determined that, like tamoxifen and fulvestrant resistance, AI resistance can also be mediated by miRNAs in $\mathrm{ER}^{+}$breast cancer. $\mathrm{Al}$ though the number of studies examining the connection between AI resistance and miRNA regulation in $\mathrm{ER}^{+}$ breast cancer is generally limited, several specific pathways appear to be the main targets associated with miRNA-mediated regulation of AI resistance.

According to a miRNA microarray using letrozole- and anastrozole-resistant MCF-7 cells, Vilquin et al. (2015) reported that both miRNA signatures in the resistant cells were associated with the regulation of the various signaling pathways, including MAPK signaling, focal adhesion, insulin signaling, ErbB signaling, and mTOR signaling pathways that converged on Akt regulation [106]. The microarray analyses determined that miR-125b, miR-205, and miR-30a were all significantly upregulated, while miR-424 was significantly downregulated, in both AI-resistant cell lines as compared to the sensitive cells. Interestingly, miR-125b and miR-205 overexpression and miR-424 suppression were able to confer resistance to both letrozole and anastrozole, as well as promote mammosphere/stem cell self-renewal, which may contribute to the aggressive nature of the resistant cells [106]. The activation of the PI3K/Akt/mTOR pathway appeared to be a critical mechanism of miR-125b/ miR-205/miR-424-mediated AI resistance. In contrast, the targeted suppression of miR-125b/miR-205 and overexpression of miR-424 may rescue the sensitivity of the cells to AIs. Clinical data demonstrating that miR-125b overexpression is correlated with decreased relapse-free survival in primary $\mathrm{ER}^{+}$breast cancer samples further support the role of miRNAs, particularly miR-125b, miR-205, and miR-424, in AI-resistance [106]. Compensatory activation of ErbB2 and downstream MAPK and Akt signaling in AI-resistant $\mathrm{ER}^{+}$breast cancer cells resulted in the upregulation of miR-21 and downregulation of its target PDCD4 [49]. In clinical cohorts of $\mathrm{ER}^{+}$breast cancer patients, PDCD4 expression is strongly linked to patient outcomes, as demonstrated by patients with low PDCD4 expression levels having poor disease-free survival and increased tumor grade. As PDCD4 is a direct target of miR-21, targeted inhibition of miR-21 significantly reduced cell proliferation in AI/letrozole-resistant MCF-7 cells in vitro [49], demonstrating that miR-21 may also be a potential target to treat AI resistance. Collectively, these preclinical and clinical data provide promising evidence regarding the potential clinical application of the targeted regulation of these miRNAs to overcome AI resistance and underscore the functional contribution of $\mathrm{PI} 3 \mathrm{~K} / \mathrm{Akt} / \mathrm{mTOR}$ pathway activation in $\mathrm{AI}$ resistance.

The TGF $\beta$ signaling pathway is another major pathway that can be modulated by miRNAs to promote AI resistance. Particularly, TGF $\beta R I$ is identified as a direct target of miR-128a, which is overexpressed in letrozole-resistant MCF-7 cells [107]. TGF $\beta$ induces a growth inhibitory effect in letrozole-sensitive cells, but does not significantly alter cell growth in the resistant cells, suggesting that the miR-128-mediated regulation of TGF $\beta$ RI may contribute to the differential responses in the letrozole-sensitive and -resistant cell lines. In turn, suppression of miR-128a was found to inhibit TGF $\beta R I$ in letrozole-resistant cells, which promoted the growth inhibitory effects of TGF $\beta$. As the correlation between miR-128a expression and letrozole resistance has only been reported in in vitro cell models, further examination in additional preclinical models and verification in clinical datasets are needed to substantiate the clinical value of miR-128a as a potential therapeutic target or marker for AI resistance.

Moreover, AI-resistant MCF7-LTED (long-term estrogen deprivation - an in vitro model of AI resistance) cells characteristically utilize glycolytic metabolism, but can switch to oxidative phosphorylation when the glycolytic pathway is impaired. The ability of AI-resistant cells to undergo this metabolic pathway reprogramming has been linked to estradiol-mediated upregulation of miR-155 [108]. Therefore, the expression of miR-155, which is reported to target hexokinase 2 (HK2) through the direct inhibition of miR-143 in head and neck squamous cell carcinoma models, is implicated in clinical AI resistance $[108,109]$. To note, HK2 is a key primer for 
glycolysis. Indeed, targeting the miR-155/miR-143-HK2 axis may be a promising strategy to overcome letrozole resistance. As well, miR-155 expression may serve as a prognostic biomarker to predict the clinical responsiveness to AIs in women with $\mathrm{ER}^{+}$breast cancer.

\section{Mechanisms that Regulate miRNA Biogenesis in $\mathrm{ER}^{+}$Breast Cancer}

As discussed previously, estrogen/ER $\alpha$ signaling can modulate the expression of various oncogenic and tumor suppressor miRNAs. However, the specific regulatory mechanisms have not been fully uncovered. In particular, the regulation of miRNA biogenesis and its functional machinery is a key mechanism that controls miRNA expression. In this section, the mechanisms of regulation and consequences of deregulated miRNA biogenesis will be discussed in context with $\mathrm{ER}^{+}$breast carcinogenesis.

The process of miRNA biogenesis and the components that form essential complexes, such as Drosha, DGCR8, Dicer1, and Ago2, have been extensively studied. Particularly, the oncogenic consequences of miRNA biogenesis deregulation have been well-documented [110-112]. Estrogen/ER $\alpha$ can modulate key machinery involved in miRNA biogenesis, which may have key functional consequences in $\mathrm{ER}^{+}$breast cancer. For instance, Dicer, a cytoplasmic endonuclease required for cleavage of the hairpin loop from the pre-miRNA, can be induced by estradiol as Dicer is reported to associate with an ER $\alpha$ binding site, which promotes Dicer mRNA transcription [32]. Accordingly, Dicer expression is upregulated in $\mathrm{ER}^{+}$breast cancer [4]. To note, Dicer expression can be modulated by miRNAs, including miR-221/222, miR-29a, and miR-200c [8]. Conversely, Ago1/2 were found to be downregulated in $\mathrm{ER}^{+}$breast cancers versus $\mathrm{ER}^{-}$breast cancers despite upregulation of other components of the RISC (i.e. Dicer and TRBP) $[4,113]$. Drosha expression was also significantly lower in $\mathrm{ER}^{+}$breast cancer samples. As well, it has been proposed that activated ER $\alpha$ may interfere with the Drosha-DGCR8 microprocessor complex that is responsible for pri-miRNA cleavage [114]. Nevertheless, as a potential functional consequence of estradiol-mediated Dicer induction and the activation of other cell signaling pathways that stimulate miRNA biogenesis, the overall expression level of miRNAs is significantly increased in $\mathrm{ER}^{+}$ breast cancer cell lines and patient samples [4, 8]. Given the differential expression/regulation of miRNA processing machinery in $\mathrm{ER}^{+}$breast cancer, it is critical to understand the factors that regulate these key components and their specific role in cancer promotion or suppression. Overall, defective miRNA biogenesis and machinery appears to be an important mechanism that ultimately contributes to ER-associated breast carcinogenesis. Thus, further exploration of these regulatory mechanisms is necessary to advance our understanding of how miRNA gene regulation can contribute to breast cancer, and may also reveal novel therapeutic strategies/targets for treating $\mathrm{ER}^{+}$breast cancer.

\section{Role of miRNAs in ER-RTK Crosstalk Regulation in Breast Cancer}

Studies unraveling the complex oncogenic signal transduction networks associated with breast cancer initiation and progression have revealed that crosstalk between key signaling pathways is an important factor contributing to breast carcinogenesis and resistance to therapeutic agents. In particular, crosstalk between the ER and RTK pathways has emerged as a critical mechanism of compensatory pathway activation, particularly in endocrine therapy-resistant $\mathrm{ER}^{+}$ breast cancers [115]. The RTK family includes a number of growth factor-mediated receptors, such as IGF1R, EGFR, and ErbB2/Her2, that are reported to promote several hallmarks of breast cancer. Arpino et al. (2005) found that high ErbB2/Her2 and EGFR expression was independently associated with a significant decrease in disease-free survival in $\mathrm{ER}^{+}$breast cancer patients taking tamoxifen [116]. Importantly, studies have found that several miRNAs can regulate targets involved in both the ER and RTK pathways, thus repressing ER-RTK crosstalk. Of particular importance, miRNAs involved in the regulation of ER-RTK crosstalk may serve as leading candidates for the development of novel miRNA-based breast cancer therapies targeting multiple oncogenic pathways.

\section{Summary and Future Perspectives}

Our review of miRNA-associated hormonal signaling in $\mathrm{ER}^{+}$breast cancer has revealed a complex signaling network that can regulate $\mathrm{ER}^{+}$breast cancer progression and response to anti-estrogen therapies. Although substantial in vitro data in conjunction with human miRNA/mRNA expression profiles have uncovered key mechanisms of miRNA regulation, functional consequences, and potential therapeutic targets, further in vivo evidence from animal models of $\mathrm{ER}^{+}$breast cancer are necessary to support the clinical application and development of miRNA-targeted therapeutics. These advances will ultimately help to identify prospective miRNA candidates for nucleic acid-based therapeutics, such as antagomiRs or miRNA sponges to suppress oncomiRs and miRNA mimics to promote the tumor suppressor miRNAs, which will further guide the clinical development and application of miRNA-based therapeutic strategies for the treatment of $\mathrm{ER}^{+}$breast cancer. Advancing our mechanistic understanding of de novo and acquired resistance to endocrine therapies and miRNA regulation will also facilitate the identification of miRNA biomarkers and the development of miRNA inhibitors/activators to enhance the efficacy of current endocrine therapies and overcome therapeutic resistance in $\mathrm{ER}^{+}$breast cancer patients. 


\section{Abbreviations}

4-OHT: 4-hydroxytamoxifen; Al: Aromatase inhibitor; $\mathrm{ER}^{+}$: Estrogen receptorpositive; ERa: Estrogen receptor alpha; HCC: Hepatocellular carcinoma; HK2: Hexokinase 2; LTED: Long-term estrogen deprivation; miRNA: microRNA; NSCLC: Non-small cell lung cancer; RTK: Receptor tyrosine kinase; SERD: Selective estrogen receptor downregulator; SERM: Selective estrogen receptor modulator; TNBC: Triple-negative breast cancer

\section{Funding}

This work was supported in part by an R21 grant from the NIEHS (5R21 ES025337-02), a U54 grant from the NIAAA (5 U54 AA019765-08), and a U54 grant from the NIMHD (1 U54 MD012392-01).

\section{Authors' Contributions}

EWH wrote the manuscript. XY contributed to conceptualization and supervision. All authors read and approved the final manuscript.

\section{Ethics Approval and Consent to Participate}

Not applicable.

\section{Consent for Publication}

Not applicable.

\section{Competing Interests}

The authors declare that they have no competing interests.

\section{Publisher's Note}

Springer Nature remains neutral with regard to jurisdictional claims in published maps and institutional affiliations.

\section{Received: 8 August 2018 Accepted: 29 August 2018}

Published online: 11 September 2018

\section{References}

1. Kondo N, Toyama T, Sugiura H, Fujii Y, Yamashita H. MiR-206 expression is down-regulated in estrogen receptor a-positive human breast cancer. Cancer Res. 2008:68:5004-8.

2. Yoshimoto N, Toyama T, Takahashi S, Sugiura H, Endo Y, Iwasa M, Fujii Y, Yamashita $\mathrm{H}$. Distinct expressions of microRNAs that directly target estrogen receptor a in human breast cancer. Breast Cancer Res Treat. 2011;130:331-9.

3. Cheang MC, Chia SK, Voduc D, Gao D, Leung S, Snider J, Watson M, Davies S, Bernard PS, Parker JS. Ki67 index, HER2 status, and prognosis of patients with luminal B breast cancer. J Natl Cancer Inst. 2009;101:736-50.

4. Blenkiron C, Goldstein LD, Thorne NP, Spiteri I, Chin S-F, Dunning MJ, Barbosa-Morais NL, Teschendorff AE, Green AR, Ellis IO, et al. MicroRNA expression profiling of human breast cancer identifies new markers of tumor subtype. Genome Biol. 2007:8:R214.

5. Nassar FJ, El Sabban M, Zgheib NK, Tfayli A, Boulos F, Jabbour M, Talhouk R, Bazarbachi A, Calin GA, Nasr R. miRNA as potential biomarkers of breast cancer in the Lebanese population and in young women: a pilot study. PLoS One. 2014;9:e107566.

6. Petrović $\mathrm{N}$, Mandušić $\mathrm{V}$, Dimitrijević B, Roganović J, Lukić $\mathrm{S}$, Todorović L, Stanojević B. Higher miR-21 expression in invasive breast carcinomas is associated with positive estrogen and progesterone receptor status in patients from Serbia. Med Oncol. 2014:31:977.

7. Xiong J, Yu D, Wei N, Fu H, Cai T, Huang Y, Wu C, Zheng X, Du Q, Lin D, Liang Z. An estrogen receptor a suppressor, microRNA-22, is downregulated in estrogen receptor a-positive human breast cancer cell lines and clinical samples. FEBS J. 2010;277:1684-94.

8. Cochrane DR, Cittelly DM, Howe EN, Spoelstra NS, McKinsey EL, LaPara K, Elias A, Yee D, Richer JK. MicroRNAs link estrogen receptor alpha status and Dicer levels in breast cancer. Hormones and Cancer. 2010;1:306-19.

9. Pandey DP, Picard D. miR-22 inhibits estrogen signaling by directly targeting the estrogen receptor a mRNA. Mol Cell Biol. 2009;29:3783-90.

10. Xu D, Takeshita F, Hino Y, Fukunaga S, Kudo Y, Tamaki A, Matsunaga J, Takahashi R-u, Takata T, Shimamoto A, et al. miR-22 represses cancer progression by inducing cellular senescence. J Cell Biol. 2011;193:409-24.

11. Leivonen S-K, Mäkelä R, Östling P, Kohonen P, Haapa-Paananen S, Kleivi K, Enerly E, Aakula A, Hellström K, Sahlberg N, et al. Protein lysate microarray analysis to identify microRNAs regulating estrogen receptor signaling in breast cancer cell lines. Oncogene. 2009;28:3926-36.
12. Di Leva G, Gasparini P, Piovan C, Ngankeu A, Garofalo M, Taccioli C, lorio MV, Li M, Volinia S, Alder H, et al. MicroRNA cluster 221-222 and estrogen receptor a interactions in breast cancer. J Natl Cancer Inst. 2010;102:706-21.

13. Adams BD, Furneaux $H$, White BA. The micro-ribonucleic acid (miRNA) miR206 targets the human estrogen receptor-a (ERa) and represses ERa messenger RNA and protein expression in breast cancer cell lines. Mol Endocrinol. 2007;21:1132-47.

14. Adams BD, Cowee DM, White BA. The role of miR-206 in the epidermal growth factor (EGF) induced repression of estrogen receptor-a (ERa) signaling and a luminal phenotype in MCF-7 breast cancer cells. Mol Endocrinol. 2009;23:1215-30.

15. Eeckhoute J, Keeton EK, Lupien M, Krum SA, Carroll JS, Brown M. Positive cross-regulatory loop ties GATA-3 to estrogen receptor a expression in breast cancer. Cancer Res. 2007;67:6477-83.

16. Y-q R, H-j W, Y-q Z, Y-b L. WBP2 modulates G1/S transition in ER+ breast cancer cells and is a direct target of miR-206. Cancer Chemother Pharmacol. 2017:79:1003-11.

17. Graveel CR, DeGroot JD, Su Y, Koeman J, Dykema K, Leung S, Snider J, Davies SR, Swiatek PJ, Cottingham S, et al. Met induces diverse mammary carcinomas in mice and is associated with human basal breast cancer. Proc Natl Acad Sci. 2009:106:12909-14.

18. Liang XH, Yu J, Brown K, Levine B. Beclin 1 contains a leucine-rich nuclear export signal that is required for its autophagy and tumor suppressor function. Cancer Res. 2001;61:3443-9.

19. Pradhan AK, Talukdar S, Bhoopathi P, Shen X-N, Emdad L, Das SK, Sarkar D, Fisher PB. mda-7/IL-24 mediates Cancer cell-specific death via regulation of miR-221 and the Beclin-1 Axis. Cancer Res. 2017;77:949-59.

20. John S, Nayvelt I, Hsu H-C, Yang P, Liu W, Das GM, Thomas T, Thomas T. Regulation of estrogenic effects by beclin 1 in breast cancer cells. Cancer Res. 2008;68:7855-63.

21. le Sage C, Nagel R, Egan DA, Schrier M, Mesman E, Mangiola A, Anile C, Maira G, Mercatelli N, Ciafrè SA, et al. Regulation of the p27Kip1 tumor suppressor by miR-221 and miR-222 promotes cancer cell proliferation. EMBO J. 2007:26:3699-708.

22. Visone R, Russo L, Pallante P, De Martino I, Ferraro A, Leone V, Borbone E, Petrocca F, Alder H, Croce CM, Fusco A. MicroRNAs (miR)-221 and miR-222, both overexpressed in human thyroid papillary carcinomas, regulate p27Kip1 protein levels and cell cycle. Endocr Relat Cancer. 2007;14:791-8.

23. Miller TE, Ghoshal K, Ramaswamy B, Roy S, Datta J, Shapiro CL, Jacob S, Majumder S. MicroRNA-221/222 confers tamoxifen resistance in breast cancer by targeting p27Kip1. J Biol Chem. 2008;283:29897-903.

24. Li Y, Liang C, Ma H, Zhao Q, Lu Y, Xiang Z, Li L, Qin J, Chen Y, Cho WC, et al. miR-221/222 promotes S-phase entry and cellular migration in control of basal-like breast cancer. Molecules. 2014;19:7122-37.

25. Garofalo M, Di Leva G, Romano G, Nuovo G, Suh S-S, Ngankeu A, Taccioli C, Pichiorri F, Alder H, Secchiero P, et al. miR-221\&222 regulate TRAll resistance and enhance tumorigenicity through PTEN and TIMP3 downregulation. Cancer Cell. 2009;16:498-509.

26. Gan R, Yang Y, Yang X, Zhao L, Lu J, Meng Q. Downregulation of miR-221/ 222 enhances sensitivity of breast cancer cells to tamoxifen through upregulation of TIMP 3. Cancer Gene Ther. 2014;21:290-6.

27. Petrovic N, Davidovic R, Jovanovic-Cupic S, Krajnovic M, Lukic S, Petrovic M, Roganovic J. Changes in miR-221/222 levels in invasive and in situ carcinomas of the breast: differences in association with estrogen receptor and TIMP3 expression levels. Molecular Diagnosis \& Therapy. 2016;20:603-15.

28. Li B, Lu Y, Wang H, Han X, Mao J, Li J, Yu L, Wang B, Fan S, Yu X, Song B. miR-221/222 enhance the tumorigenicity of human breast cancer stem cells via modulation of PTEN/Akt pathway. Biomed Pharmacother. 2016;79:93-101.

29. Zhang C, Zhang J, Zhang A, Wang Y, Han L, You Y, Pu P, Kang C. PUMA is a novel target of miR-221/222 in human epithelial cancers. Int J Oncol. 2010; 37:1621-6.

30. Young J, Kawaguchi T, Yan L, Qi Q, Liu S, Takabe K. Tamoxifen sensitivityrelated microRNA-342 is a useful biomarker for breast cancer survival. Oncotarget. 2017:8:99978-89.

31. Han S-H, Kim HJ, Gwak JM, Kim M, Chung YR, Park SY. MicroRNA-222 expression as a predictive marker for tumor progression in hormone receptor-positive breast cancer. J Breast Cancer. 2017;20:35-44.

32. Bhat-Nakshatri P, Wang G, Collins NR, Thomson MJ, Geistlinger TR, Carroll JS, Brown M, Hammond S, Srour EF, Liu Y, Nakshatri H. Estradiol-regulated 
microRNAs control estradiol response in breast cancer cells. Nucleic Acids Res. 2009:37:4850-61.

33. Frankel LB, Christoffersen NR, Jacobsen A, Lindow M, Krogh A, Lund AH. Programmed cell death 4 (PDCD4) is an important functional target of the microRNA miR-21 in breast cancer cells. J Biol Chem. 2008;283:1026-33.

34. Song $B$, Wang C, Liu J, Wang X, LV L, Wei L, Xie L, Zheng Y, Song X. MicroRNA-21 regulates breast cancer invasion partly by targeting tissue inhibitor of metalloproteinase 3 expression. J Exp Clin Cancer Res. 2010;29:29.

35. Meng F, Henson R, Wehbe-Janek H, Ghoshal K, Jacob ST, Patel T. MicroRNA21 regulates expression of the PTEN tumor suppressor gene in human hepatocellular cancer. Gastroenterology. 2007;133:647-58.

36. Iorio MV, Ferracin M, Liu C-G, Veronese A, Spizzo R, Sabbioni S, Magri E, Pedriali M, Fabbri M, Campiglio M, et al. MicroRNA gene expression deregulation in human breast cancer. Cancer Res. 2005;65:7065-70.

37. Petrović N, Mandušić V, Stanojević B, Lukić S, Todorović L, Roganović J, Dimitrijević $\mathrm{B}$. The difference in miR-21 expression levels between invasive and non-invasive breast cancers emphasizes its role in breast cancer invasion. Med Oncol. 2014;31:867.

38. Petrović N. miR-21 might be involved in breast cancer promotion and invasion rather than in initial events of breast cancer development. Mol Diagn Ther. 2016;20:97-110.

39. Masuda M, Miki Y, Hata S, Takagi K, Sakurai M, Ono K, Suzuki K, Yang Y, Abe $\mathrm{E}$, Hirakawa $\mathrm{H}$, et al. An induction of microRNA, miR-7 through estrogen treatment in breast carcinoma. J Transl Med. 2012;10(Suppl 1):S2.

40. Maillot $G$, Lacroix-Triki M, Pierredon S, Gratadou L, Schmidt S, Bénès $V$, Roché H, Dalenc F, Auboeuf D, Millevoi S, Vagner S. Widespread estrogendependent repression of micrornas involved in breast tumor cell growth. Cancer Res. 2009;69:8332-40.

41. Wickramasinghe NS, Manavalan TT, Dougherty SM, Riggs KA, Li Y, Klinge CM. Estradiol downregulates miR-21 expression and increases miR-21 target gene expression in MCF-7 breast cancer cells. Nucleic Acids Res. 2009;37: 2584-95.

42. Manavalan TT, Teng Y, Appana SN, Datta S, Kalbfleisch TS, Li Y, Klinge CM. Differential expression of microRNA expression in tamoxifen-sensitive MCF-7 versus tamoxifen-resistant LY2 human breast cancer cells. Cancer Lett. 2011; 313:26-43.

43. Selcuklu SD, Donoghue MT, Kerin MJ, Spillane C. Regulatory interplay between miR-21, JAG1 and 17beta-estradiol (E2) in breast cancer cells. Biochem Biophys Res Commun. 2012;423:234-9.

44. Klinge CM, Riggs KA, Wickramasinghe NS, Emberts CG, McConda DB, Barry $\mathrm{PN}$, Magnusen JE. Estrogen receptor alpha 46 is reduced in tamoxifen resistant breast cancer cells and re-expression inhibits cell proliferation and estrogen receptor alpha 66-regulated target gene transcription. Mol Cell Endocrinol. 2010;323:268-76.

45. LeMay-Nedjelski L, Mason-Ennis JK, Taibi A, Comelli EM, Thompson LU. Omega-3 Polyunsaturated Fatty Acids Time-Dependently Reduce Cell Viability and Oncogenic MicroRNA-21 Expression in Estrogen Receptor-Positive Breast Cancer Cells (MCF-7). Int J Mol Sci. 2018;19:E244

46. Yu X, Li R, Shi W, Jiang T, Wang Y, Li C, Qu X. Silencing of MicroRNA-21 confers the sensitivity to tamoxifen and fulvestrant by enhancing autophagic cell death through inhibition of the PI3K-AKT-mTOR pathway in breast cancer cells. Biomed Pharmacother. 2016;77:37-44.

47. Khori V, Shalamzari SA, Isanejad A, Alizadeh AM, Alizadeh S, Khodayari S, Khodayari H, Shahbazi S, Zahedi A, Sohanaki H, et al. Effects of exercise training together with tamoxifen in reducing mammary tumor burden in mice: possible underlying pathway of miR-21. Eur $J$ Pharmacol. 2015;765:179-87.

48. Isanejad A, Alizadeh AM, Shalamzari SA, Khodayari H, Khodayari S, Khori V, Khojastehnjad N. MicroRNA-206, let-7a and microRNA-21 pathways involved in the anti-angiogenesis effects of the interval exercise training and hormone therapy in breast cancer. Life Sci. 2016;151:30-40.

49. Chen Z, Yuan Y-C, Wang Y, Liu Z, Chan HJ, Chen S. Down-regulation of programmed cell death 4 (PDCD4) is associated with aromatase inhibitor resistance and a poor prognosis in estrogen receptor-positive breast cancer. Breast Cancer Res Treat. 2015;152:29-39.

50. Foekens JA, Sieuwerts AM, Smid M, Look MP, de Weerd V, Boersma AW, Klijn JG, Wiemer EA, Martens JW. Four miRNAs associated with aggressiveness of lymph node-negative, estrogen receptor-positive human breast cancer. Proc Natl Acad Sci U S A. 2008;105:13021-6.
51. Lyng MB, Lænkholm A-V, Søkilde R, Gravgaard KH, Litman T, Ditzel HJ. Global microRNA expression profiling of high-risk ER+ breast cancers from patients receiving adjuvant tamoxifen mono-therapy: a DBCG study. PLoS One. 2012;7:e36170

52. Cui Y-X, Bradbury R, Flamini V, Wu B, Jordan N, Jiang WG. MicroRNA-7 suppresses the homing and migration potential of human endothelial cells to highly metastatic human breast cancer cells. Br J Cancer. 2017; 117:89-101.

53. Shi Y, Luo X, Li P, Tan J, Wang X, Xiang T, Ren G. miR-7-5p suppresses cell proliferation and induces apoptosis of breast cancer cells mainly by targeting REGY. Cancer Lett. 2015;358:27-36.

54. Kefas B, Godlewski J, Comeau L, Li Y, Abounader R, Hawkinson M, Lee J, Fine H, Chiocca EA, Lawler S, Purow B. microRNA-7 inhibits the epidermal growth factor receptor and the Akt pathway and is down-regulated in glioblastoma. Cancer Res. 2008;68:3566-72.

55. Webster RJ, Giles KM, Price KJ, Zhang PM, Mattick JS, Leedman PJ. Regulation of epidermal growth factor receptor signaling in human cancer cells by microRNA-7. J Biol Chem. 2009;284:5731-41.

56. Jiang L, Liu X, Chen Z, Jin Y, Heidbreder CE, Kolokythas A, Wang A, Dai Y, Zhou X. MicroRNA-7 targets IGF1R (insulin-like growth factor 1 receptor) in tongue squamous cell carcinoma cells. Biochem J. 2010;432:199-205.

57. Castellano L, Giamas G, Jacob J, Coombes RC, Lucchesi W, Thiruchelvam P, Barton $G$, Jiao $L R$, Wait $R$, Waxman J, et al. The estrogen receptor-a-induced microRNA signature regulates itself and its transcriptional response. Proceedings of the National Academy of Sciences U S A. 2009;106:15732-7.

58. O'Donnell KA, Wentzel EA, Zeller KI, Dang CV, Mendell JT. C-Myc-regulated microRNAs modulate E2F1 expression. Nature. 2005;435:839-43.

59. Kovalchuk O, Tryndyak VP, Montgomery B, Boyko A, Kutanzi K, Zemp F, Warbritton AR, Latendresse JR, Kovalchuk I, Beland FA, Pogribny IP. Estrogen-induced rat breast carcinogenesis is characterized by alterations in DNA methylation, histone modifications, and aberrant microRNA expression. Cell Cycle. 2007;6:2010-8.

60. Liao XH, Lu DL, Wang N, Liu LY, Wang Y, Li YQ, Yan TB, Sun XG, Hu P, Zhang TC. Estrogen receptor a mediates proliferation of breast cancer MCF-7 cells via a p21/PCNA/E2F1-dependent pathway. FEBS J. 2014;281:927-42.

61. Yu Z, Wang C, Wang M, Li Z, Casimiro MC, Liu M, Wu K, Whittle J, Ju X, Hyslop T, et al. A cyclin D1/microRNA 17/20 regulatory feedback loop in control of breast cancer cell proliferation. J Cell Biol. 2008;182:509-17.

62. He M, Wang Q-Y, Yin Q-Q, Tang J, Lu Y, Zhou C-X, Duan C-W, Hong D-L, Tanaka T, Chen G-Q, Zhao Q. HIF-1a downregulates miR-17/20a directly targeting p21 and STAT3: a role in myeloid leukemic cell differentiation. Cell Death Differ. 2013;20:408-18.

63. Liao X-H, Xiang Y, Yu C-X, Li J-P, Li H, Nie Q, Hu P, Zhou J, Zhang T-C. STAT3 is required for MiR-17-5p-mediated sensitization to chemotherapy-induced apoptosis in breast cancer cells. Oncotarget. 2017;8:15763-74.

64. Hossain A, Kuo MT, Saunders GF. Mir-17-5p regulates breast cancer cell proliferation by inhibiting translation of AIB1 mRNA. Mol Cell Biol. 2006:26:8191-201.

65. Louie MC, Zou JX, Rabinovich A, Chen H-W. ACTR/AIB1 functions as an E2F1 coactivator to promote breast cancer cell proliferation and antiestrogen resistance. Mol Cell Biol. 2004;24:5157-71.

66. Osborne CK, Bardou V, Hopp TA, Chamness GC, Hilsenbeck SG, Fuqua SA, Wong J, Allred DC, Clark GM, Schiff R. Role of the estrogen receptor coactivator AIB1 (SRC-3) and HER-2/neu in tamoxifen resistance in breast cancer. J Natl Cancer Inst. 2003;95:353-61.

67. Zhu J, Zou Z, Nie P, Kou X, Wu B, Wang S, Song Z, He J. Downregulation of microRNA-27b-3p enhances tamoxifen resistance in breast cancer by increasing NR5A2 and CREB1 expression. Cell Death Dis. 2016;7:e2454

68. Tang W, Zhu J, Su S, Wu W, Liu Q, Su F, Yu F. MiR-27 as a prognostic marker for breast cancer progression and patient survival. PLoS One. 2012;7:e51702.

69. Li X, Mertens-Talcott SU, Zhang S, Kim K, Ball J, Safe S. MicroRNA-27a indirectly regulates estrogen receptor a expression and hormone responsiveness in MCF-7 breast cancer cells. Endocrinology. 2010;151:2462-73.

70. Mertens-Talcott SU, Chintharlapalli S, Li X, Safe S. The oncogenic microRNA27 a targets genes that regulate specificity protein transcription factors and the G2-M checkpoint in MDA-MB-231 breast cancer cells. Cancer Res. 2007; 67:11001-11.

71. Tsuchiya Y, Nakajima M, Takagi S, Taniya T, Yokoi T. MicroRNA regulates the expression of human cytochrome P450 1B1. Cancer Res. 2006;66:9090-8. 
72. Thiruchelvam PT, Lai C-F, Hua H, Thomas RS, Hurtado A, Hudson W, Bayly AR, Kyle FJ, Periyasamy M, Photiou A, et al. The liver receptor homolog-1 regulates estrogen receptor expression in breast cancer cells. Breast Cancer Res Treat. 2011;127:385-96.

73. Bianco S, Brunelle M, Jangal M, Magnani L, Gévry N. LRH-1 governs vital transcriptional programs in endocrine-sensitive and-resistant breast cancer cells. Cancer Res. 2014;74:2015-25.

74. Lee M-J, Yoon K-S, Cho K-W, Kim K-S, Jung H-S. Expression of miR-206 during the initiation of mammary gland development. Cell Tissue Res. 2013; 353:425-33.

75. Simonini PSR, Breiling A, Gupta N, Malekpour M, Youns M, Omranipour R, Malekpour F, Volinia S, Croce CM, Najmabadi H, et al. Epigenetically deregulated microRNA-375 is involved in a positive feedback loop with estrogen receptor a in breast cancer cells. Cancer Res. 2010;70:9175-84.

76. Chang Y, Yan W, He X, Zhang L, Li C, Huang H, Nace G, Geller DA, Lin J, Tsung A. miR-375 inhibits autophagy and reduces viability of hepatocellular carcinoma cells under hypoxic conditions. Gastroenterology. 2012;143:177-87.

77. Liu X, Wang J, Dong Y. The inhibitory effect of miR-375 targeting sp1 in colorectal cancer cell proliferation. Eur Rev Med Pharmacol Sci. 2018; 22:405-11.

78. Wang F, Li Y, Zhou J, Xu J, Peng C, Ye F, Shen Y, Lu W, Wan X, Xie X. miR375 is down-regulated in squamous cervical cancer and inhibits cell migration and invasion via targeting transcription factor SP1. Am J Pathol. 2011;179:2580-8

79. (EBCTCG) EBCTCG, Davies C, Godwin J, Gray R, Clarke M, Cutter D, Darby S, McGale P, Pan H, Taylor C, et al. Relevance of breast cancer hormone receptors and other factors to the efficacy of adjuvant tamoxifen: patient-level meta-analysis of randomised trials. Lancet. 2011; 378:771-84.

80. Ring A, Dowsett M. Mechanisms of tamoxifen resistance. Endocr Relat Cancer. 2004;11:643-58.

81. Wei Y, Lai X, Yu S, Chen S, Ma Y, Zhang Y, Li H, Zhu X, Yao L, Zhang J. Exosomal miR-221/222 enhances tamoxifen resistance in recipient ERpositive breast cancer cells. Breast Cancer Res Treat. 2014;147:423-31.

82. Liu W-H, Yeh S-H, Lu C-C, Yu S-L, Chen H-Y, Lin C-Y, Chen D-S, Chen P-J. MicroRNA-18a prevents estrogen receptor-a expression, promoting proliferation of hepatocellular carcinoma cells. Gastroenterology. 2009; 136:683-93

83. Wu Q, Guo L, Jiang F, Li L, Li Z, Chen F. Analysis of the miRNA-mRNAIncRNA networks in ER+ and ER- breast cancer cell lines. J Cell Mol Med. 2015;19:2874-87.

84. Devulapally R, Sekar TV, Paulmurugan R. Formulation of anti-miR-21 and 4-hydroxytamoxifen co-loaded biodegradable polymer nanoparticles and their antiproliferative effect on breast cancer cells. Mol Pharm. 2015;12: 2080-92.

85. Muppala S, Mudduluru G, Leupold JH, Buergy D, Sleeman JP, Allgayer H. CD24 induces expression of the oncomir miR-21 via Src, and CD24 and Src are both post-transcriptionally downregulated by the tumor suppressor miR-34a. PLoS One. 2013;8:e59563.

86. Kim HJ, Kim M-J, Ahn SH, Son BH, Kim SB, Ahn JH, Noh WC, Gong G. Different prognostic significance of CD24 and CD44 expression in breast cancer according to hormone receptor status. Breast. 2011;20:78-85.

87. Castoria G, Giovannelli P, Lombardi M, De Rosa C, Giraldi T, De Falco A, Barone M, Abbondanza C, Migliaccio A, Auricchio F. Tyrosine phosphorylation of estradiol receptor by Src regulates its hormonedependent nuclear export and cell cycle progression in breast cancer cells. Oncogene. 2012;31:4868-77.

88. Ikeda K, Horie-Inoue K, Ueno T, Suzuki T, Sato W, Shigekawa T, Osaki A, Saeki T, Berezikov E, Mano H, Inoue S. miR-378a-3p modulates tamoxifen sensitivity in breast cancer MCF-7 cells through targeting GOLT1A. Sci Rep. 2015;5:13170.

89. Ye P, Fang C, Zeng H, Shi Y, Pan Z, An N, He K, Zhang L, Long X. Differential microRNA expression profiles in tamoxifen-resistant human breast cancer cell lines induced by two methods. Oncol Lett. 2018;15:3532-9.

90. Phuong NTT, Lim SC, Kim YM, Kang KW. Aromatase induction in tamoxifenresistant breast cancer: role of phosphoinositide 3-kinase-dependent CREB activation. Cancer Lett. 2014;351:91-9.

91. Cittelly DM, Das PM, Spoelstra NS, Edgerton SM, Richer JK, Thor AD, Jones FE. Downregulation of miR-342 is associated with tamoxifen resistant breast tumors. Mol Cancer. 2010;9:317.
92. He YJ, Wu JZ, Ji MH, Ma T, Qiao EQ, Ma R, Tang JH. miR-342 is associated with estrogen receptor-a expression and response to tamoxifen in breast cancer. Exp Ther Med. 2013;5:813-8.

93. Knowlden JM, Hutcheson IR, Jones HE, Madden T, Gee JM, Harper ME, Barrow D, Wakeling AE, Nicholson RI. Elevated levels of epidermal growth factor receptor/c-erbB2 heterodimers mediate an autocrine growth regulatory pathway in tamoxifen-resistant MCF-7 cells. Endocrinology. 2003; 144:1032-44.

94. Pancholi S, Lykkesfeldt AE, Hilmi C, Banerjee S, Leary A, Drury S, Johnston S, Dowsett M, Martin L-A. ERBB2 influences the subcellular localization of the estrogen receptor in tamoxifen-resistant MCF-7 cells leading to the activation of AKT and RPS6KA2. Endocr Relat Cancer. 2008;15:985-1002.

95. Di Leva G, Cheung DG, Croce CM. miRNA clusters as therapeutic targets for hormone-resistant breast cancer. Expert Review of Endocrinology \& Metabolism. 2015;10:607-17.

96. Jansen M, Reijm EA, Sieuwerts AM, Ruigrok-Ritstier K, Look MP, RodríguezGonzález FG, Heine AA, Martens JW, Sleijfer S, Foekens JA, Berns E. High miR-26a and low CDC2 levels associate with decreased EZH2 expression and with favorable outcome on tamoxifen in metastatic breast cancer. Breast Cancer Res Treat. 2012;133:937-47.

97. Wang $Y$, Zhang $X$, Chao Z, Kung HF, Lin MC, Dress A, Wardle F, Jiang BH, Lai L. MiR-34a modulates ErbB2 in breast cancer. Cell Biol Int. 2017;41:93-101.

98. Gu Y, Chen T, Li G, Xu C, Xu Z, Zhang J, He K, Zheng L, Guan Z, Su X, et al. Lower Beclin 1 downregulates HER2 expression to enhance tamoxifen sensitivity and predicts a favorable outcome for ER positive breast cancer. Oncotarget. 2017;8:52156-77.

99. Zhou Q, Zeng H, Ye P, Shi Y, Guo J, Long X. Differential microRNA profiles between fulvestrant-resistant and tamoxifen-resistant human breast cancer cells. Anti-Cancer Drugs. 2018;29(6):539-48.

100. Rao X, Di Leva G, Li M, Fang F, Devlin C, Hartman-Frey C, Burow M, Ivan M, Croce CM, Nephew K. MicroRNA-221/222 confers breast cancer fulvestrant resistance by regulating multiple signaling pathways. Oncogene. 2011;30:1082-97.

101. Sansone P, Berishaj M, Rajasekhar VK, Ceccarelli C, Chang Q, Strillacci A, Savini C, Shapiro L, Bowman RL, Mastroleo C, et al. Evolution of cancer stem-like cells in endocrine-resistant metastatic breast cancers is mediated by stromal microvesicles. Cancer Res. 2017;77:1927-41.

102. Fan M, Yan PS, Hartman-Frey C, Chen L, Paik H, Oyer SL, Salisbury JD, Cheng AS, Li L, Abbosh PH, et al. Diverse gene expression and DNA methylation profiles correlate with differential adaptation of breast cancer cells to the antiestrogens tamoxifen and fulvestrant. Cancer Res. 2006;66:11954-66.

103. Nam S, Long X, Kwon C, Kim S, Nephew KP. An integrative analysis of cellular contexts, miRNAs and mRNAs reveals network clusters associated with antiestrogen-resistant breast cancer cells. BMC Genomics. 2012;13:732.

104. Liu L, Shen W, Zhu Z, Lin J, Fang Q, Ruan Y, Zhao H. Combined inhibition of EGFR and C-ABL suppresses the growth of fulvestrant-resistant breast cancer cells through miR-375-autophagy axis. Biochem Biophys Res Commun. 2018:498:559-65.

105. Yu X, Luo A, Liu Y, Wang S, Li Y, Shi W, Liu Z, Qu X. MiR-214 increases the sensitivity of breast cancer cells to tamoxifen and fulvestrant through inhibition of autophagy. Mol Cancer. 2015;14:208.

106. Vilquin P, Donini CF, Villedieu M, Grisard E, Corbo L, Bachelot T, Vendrell JA, Cohen PA. MicroRNA-125b upregulation confers aromatase inhibitor resistance and is a novel marker of poor prognosis in breast cancer. Breast Cancer Res. 2015;17:13.

107. Masri S, Liu Z, Phung S, Wang E, Yuan Y-C, Chen S. The role of microRNA$128 \mathrm{a}$ in regulating TGFbeta signaling in letrozole-resistant breast cancer cells. Breast Cancer Res Treat. 2010;124:89-99.

108. Bacci M, Giannoni E, Fearns A, Ribas R, Gao Q, Taddei ML, Pintus G, Dowsett M, Isacke CM, Martin L-A, et al. miR-155 drives metabolic reprogramming of ER+ breast cancer cells following long-term estrogen deprivation and predicts clinical response to aromatase inhibitors. Cancer Res. 2016;76:1615-26.

109. Peschiaroli A, Giacobbe A, Formosa A, Markert E, Bongiorno-Borbone L, Levine A, Candi E, D'alessandro A, Zolla L, Agrò AF, Melino G. miR-143 regulates hexokinase 2 expression in cancer cells. Oncogene. 2013;32:797-802.

110. Gregory Rl, Shiekhattar R. MicroRNA biogenesis and cancer. Cancer Res. 2005;65:3509-12.

111. Esquela-Kerscher A, Slack FJ. Oncomirs-microRNAs with a role in cancer. Nat Rev Cancer. 2006;6:259-69.

112. Lin S, Gregory Rl. MicroRNA biogenesis pathways in cancer. Nat Rev Cancer. 2015;15:321-33. 
113. Cheng C, Fu X, Alves P, Gerstein M. mRNA expression profiles show differential regulatory effects of microRNAs between estrogen receptor-positive and estrogen receptor-negative breast cancer. Genome Biol. 2009;10:R90.

114. Macias S, Michlewski G, Cáceres JF. Hormonal regulation of microRNA biogenesis. Mol Cell. 2009;36:172-3.

115. Arpino G, Wiechmann L, Osborne CK, Schiff R. Crosstalk between the estrogen receptor and the HER tyrosine kinase receptor family: molecular mechanism and clinical implications for endocrine therapy resistance. Endocr Rev. 2008;29:217-33.

116. Arpino G, Weiss H, Lee AV, Schiff R, De Placido S, Osborne CK, Elledge RM. Estrogen receptor-positive, progesterone receptor-negative breast cancer: association with growth factor receptor expression and tamoxifen resistance. J Natl Cancer Inst. 2005;97:1254-61.

117. Chou C-H, Shrestha S, Yang C-D, Chang N-W, Lin Y-L, Liao K-W, Huang W-C, Sun T-H, Tu S-J, Lee W-H, et al. miRTarBase update 2018: a resource for experimentally validated microRNA-target interactions. Nucleic Acids Res. 2018;46:D296-302.

118. Zhou X, Marian C, Makambi KH, Kosti O, Kallakury BV, Loffredo CA, Zheng YL. MicroRNA-9 as potential biomarker for breast cancer local recurrence and tumor estrogen receptor status. PLoS One. 2012;7:e39011.

119. Kolacinska A, Morawiec J, Pawlowska Z, Szemraj J, Szymanska B, Malachowska B, Morawiec Z, Morawiec-Sztandera A, Pakula L, Kubiak R, Zawlik I. Association of microRNA-93, 190, 200b and receptor status in core biopsies from stage III breast cancer patients. DNA Cell Biol. 2014;33:624-9.

120. van Schooneveld E, Wildiers H, Vergote I, Vermeulen PB, Dirix LY, Van Laere SJ. Dysregulation of microRNAs in breast cancer and their potential role as prognostic and predictive biomarkers in patient management. Breast Cancer Res. 2015;17:21.

121. Jegg A-M, Ward TM, lorns E, Hoe N, Zhou J, Liu X, Singh S, Landgraf R, Pegram MD. PI3K independent activation of mTORC1 as a target in lapatinib-resistant ERBB2+ breast cancer cells. Breast Cancer Res Treat. 2012;136:683-92.

122. Lowery AJ, Miller N, Devaney A, McNeill RE, Davoren PA, Lemetre C, Benes V, Schmidt S, Blake J, Ball G, Kerin MJ. MicroRNA signatures predict oestrogen receptor, progesterone receptor and HER2/neu receptor status in breast cancer. Breast Cancer Res. 2009;11:R27.

123. Crippa E, Lusa L, De Cecco L, Marchesi E, Calin GA, Radice P, Manoukian S, Peissel B, Daidone MG, Gariboldi M, Pierotti MA. miR-342 regulates BRCA1 expression through modulation of ID4 in breast cancer. PLoS One. 2014;9:e87039.

124. Ward A, Shukla K, Balwierz A, Soons Z, König R, Sahin Ö, Wiemann S. MicroRNA-519a is a novel oncomir conferring tamoxifen resistance by targeting a network of tumour-suppressor genes in ER+ breast cancer. J Pathol. 2014;233:368-79.

125. Pillai MM, Gillen AE, Yamamoto TM, Kline E, Brown J, Flory K, Hesselberth JR, Kabos P. HITS-CLIP reveals key regulators of nuclear receptor signaling in breast cancer. Breast Cancer Res Treat. 2014;146:85-97.

126. Egeland NG, Lunde $S$, Jonsdottir $K$, Lende TH, Cronin-Fenton D, Gilje B, Janssen EA, Søiland $\mathrm{H}$. The role of microRNAs as predictors of response to tamoxifen treatment in breast cancer patients. Int J Mol Sci. 2015;16:24243-75.

127. Chen L, Zheng J, Zhang Y, Yang L, Wang J, Ni J, Cui D, Yu C, Cai Z. Tumorspecific expression of microRNA-26a suppresses human hepatocellular carcinoma growth via cyclin-dependent and-independent pathways. Mol Ther. 2011;19:1521-8.

128. Spizzo R, Nicoloso M, Lupini L, Lu Y, Fogarty J, Rossi S, Zagatti B, Fabbri M, Veronese A, Liu X, et al. miR-145 participates with TP53 in a deathpromoting regulatory loop and targets estrogen receptor-a in human breast cancer cells. Cell Death Differ. 2010;17:246-54.

129. Kim YS, Park SJ, Lee YS, Kong HK, Park JH. miRNAs involved in LY6K and estrogen receptor a contribute to tamoxifen-susceptibility in breast cancer. Oncotarget. 2016;7:42261-73.

130. Martin EC, Conger AK, Yan TJ, Hoang VT, Miller DF, Buechlein A, Rusch DB, Nephew KP, Collins-Burow BM, Burow ME. MicroRNA-335-5p and-3p synergize to inhibit estrogen receptor alpha expression and promote tamoxifen resistance. FEBS Lett. 2017;591:382-92.

131. Fang $D$, Yang $H$, Lin J, Teng $Y$, Jiang $Y$, Chen J, Li Y. 17ß-estradiol regulates cell proliferation, colony formation, migration, invasion and promotes apoptosis by upregulating miR-9 and thus degrades MALAT-1 in osteosarcoma cell MG-63 in an estrogen receptor-independent manner. Biochem Biophys Res Commun. 2015:457:500-6.

132. Tilghman SL, Bratton MR, Segar HC, Martin EC, Rhodes LV, Li M, McLachlan JA, Wiese TE, Nephew KP, Burow ME. Endocrine disruptor regulation of microRNA expression in breast carcinoma cells. PLoS One. 2012;7:e32754.
133. Singh B, Ronghe AM, Chatterjee A, Bhat NK, Bhat HK. MicroRNA-93 regulates NRF2 expression and is associated with breast carcinogenesis. Carcinogenesis. 2013;34:1165-72.

134. Jiang C-F, Shi Z-M, Li D-M, Qian Y-C, Ren Y, Bai X-M, Xie Y-X, Wang L, Ge X, Liu W-T, et al. Estrogen-induced miR-196a elevation promotes tumor growth and metastasis via targeting SPRED1 in breast cancer. Mol Cancer. 2018;17:83.

135. Baran-Gale J, Purvis JE, Sethupathy P. An integrative transcriptomics approach identifies miR-503 as a candidate master regulator of the estrogen response in MCF-7 breast cancer cells. RNA. 2016;22:1592-603.

136. Tao S, He H, Chen Q. Estradiol induces HOTAIR levels via GPER-mediated miR-148a inhibition in breast cancer. J Transl Med. 2015;13:131.

137. Kastrati I, Canestrari E, Frasor J. PHLDA1 expression is controlled by an estrogen receptor-NFKB-miR-181 regulatory loop and is essential for formation of ER+ mammospheres. Oncogene. 2015:34:2309-16.
Ready to submit your research? Choose BMC and benefit from:

- fast, convenient online submission

- thorough peer review by experienced researchers in your field

- rapid publication on acceptance

- support for research data, including large and complex data types

- gold Open Access which fosters wider collaboration and increased citations

- maximum visibility for your research: over $100 \mathrm{M}$ website views per year

At BMC, research is always in progress.

Learn more biomedcentral.com/submissions 